University of Louisville

ThinkIR: The University of Louisville's Institutional Repository

1954

\title{
A comparison of the responses of students and teachers concerning what was taught in high school senior English.
}

Beatrice Lewis Reynolds

University of Louisville

Follow this and additional works at: https://ir.library.louisville.edu/etd

Part of the Education Commons, and the English Language and Literature Commons

\section{Recommended Citation}

Reynolds, Beatrice Lewis, "A comparison of the responses of students and teachers concerning what was taught in high school senior English." (1954). Electronic Theses and Dissertations. Paper 2556.

https://doi.org/10.18297/etd/2556

This Master's Thesis is brought to you for free and open access by ThinkIR: The University of Louisville's Institutional Repository. It has been accepted for inclusion in Electronic Theses and Dissertations by an authorized administrator of ThinkIR: The University of Louisville's Institutional Repository. This title appears here courtesy of the author, who has retained all other copyrights. For more information, please contact thinkir@louisville.edu. 
A GOMPARISON OF THE RESPONSES OF STUDTETS AND TEACHERS CONOBHA INO WHAT WAS TAUOHF

II BİG sCHOOL BEIOR EOLISH

\author{
A Profesaional Paper \\ subiltied to the paeulty \\ of the araduate Sohool of the Oniveralty of Loulavizle \\ In Partiel Pulfiliment of the \\ Requir remente for the Degree \\ of Naster of edueation
}

Departamt of Duoation

by

Beatriee Low1s Rognolds

Yoar

1954 
WAMB of STODnX?

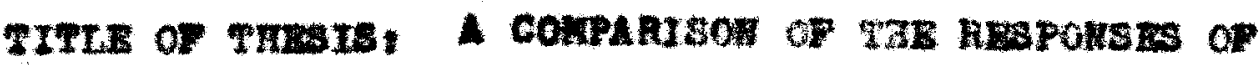

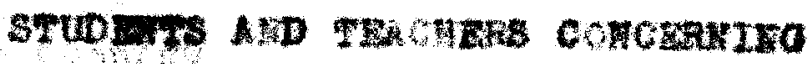

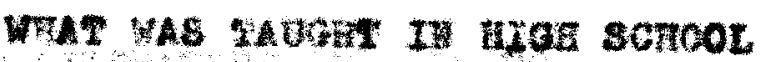
SEIOA Hot.ISE

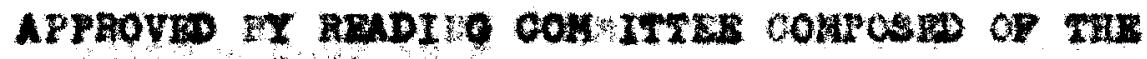

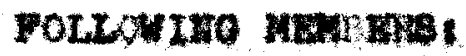

WAME OF SPOASOR:

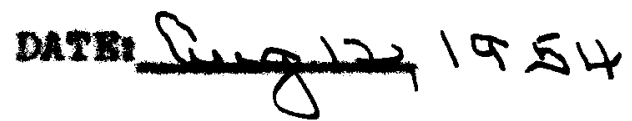


TABLE OF COMTETS

CHAPTER

PAOS

I. STAtEatir OF THE PROBLA

II. A REVIEW OF SOKE LITERATURE RELATED TO THE PROELEA

III. HBYHOD AID SUBJECTS 16

IV. DESCRIPTIOR OF THE SUBJEOT8

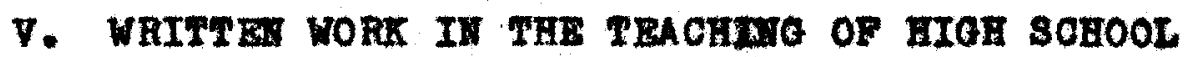

SEWIOR WOLISH

VI. OTHER TOPICS RELATE TO THE TEACHIMO OF EHOLISR

54

vII. SUMAFX AMD conorustoms

84

BIBLIOORAPHX

94

APPEIDIX

98 


\section{LIST OF TABLES}

TABLR

PAOB

I. Tabulation by Ono-joar Age perloda, Showing

Jubar of 155 colloge Freshmen in Bach Age Group

200

II. A Tabulation showing the Total Payohology Beores of 359 Oniverelty of Leulevil2e Frowben tho Were surveyed for Inglith studied in Elgh-wehoel Soalor Delioh

21

III. A Tabulation showing the Total mglioh seores of 359 Unlversity of Louleville Mreabmen tho Were Burvered for Dnglioh studied in Elgh-gehool Sontor Rnglish

IV. A rabulation Showing the zotal cosiomal Oulture soores of 359 Univerwity of Louleri11. Freaheon Who Wore Survoged for Inglish Studied in Highsohool sentor Bngliah

v. A Tabulation by number and por cont, shouling Written Work Done by students of sonior Highsohool Bagliah Compared to What Toahore of High-sohool Mnglish Indioate They Beguired

VI. I Tabulation by Wuber and For Oent, Shoulng Themes Written by studente of High-eohool Ben10r Dnglieh Compared to Themes Teachors of High-eohool Sonior Bnglish Toriohers Indiated They Required 
VII. A Tabulation showing the soure of subjecte for Writton Work in Highmeohool Senlor English as Indleated by 155 College Freammen and Compared to the Souree of Subjeate an Indiested by 25 Teachers of High-sohool sentor Dalish

vIII. A Tabulation showing Types of Writing Done as Choeked by 155 College Freahnon as Comparod to Type Toachere Indloated they Required, Tabulated by Iumber and Por cent.

IX. A Tabulation by Iuber and Por Cent Showing the Proparation for Writing Thomes As Indieated bJ 155 Froabmon and Compared to Proparation as Indicated by 25 Teaohers of Highmohool senior Bnglish in Louleville and Jofferson County. Kontuokg

X. A Tabulation by Number and per Gent showing the Wothode of Grading and Rovising of Themes as Indlosted by 155 College Frouhuen And Compared to the Mothode Indleated by 25 Teachore of High-gehool sentor mglish in Louleville and Jorforwon County, Kontuoks 
XI. A Comparisen of the Rooponate of the 155 colloge Froubsen Conournteg Hother thoy Hoedred Latter Orades in High-ophool Bonier Inglith to the Responses of the 25 rosehore Conoerning whother thoy gave Lotter orades, rabulated by Iruber and Per Cont

XII. A Comparian of Item Oheoked by 155 College Fresheen Concerning IIme Thomes Nore Roturned In Frelfth Grade Daglish olases to Itome Chouked by 25 reachers of Iwelfth Grade mingh, rabulated by Tumber and Per cent

III. A Tabulation Coupering Items Chooked by Teachere of Trelfth orade Inglieh on the Handing of Themos after Correotions Vere Made to Itame Cheoked by 155 0ollege Proshmen, by Jumber and Per Cent

XIV. A Tebulation Shoulag How Papars Wore Rovised as Indlaxted by Boplies of 155 Colloge Freshmen and Compared to Anawers of 25 roacharw of H1gh-eopoel Sontor raglith, by Buber and Pes Gont

XV. A rabulation by Hwober and Per Oent Comparine the Tlust Disposition of momes as Indleated by 155 Colloge Froumen and 25 reachor of Elgh-sohool sontov saglian 
XVI. A Tabulation Bhowing Rumber and Per Cont of Those tho Indieated Eaving Had Formal Lossons In Spolilng as Aonlor in HIgh-ocbool Anglinh al Cowperved to Ioechow of IIgh-oohool Bnglish Wo Indieatod Having Taught Pormal Lessows in Spelling, and Whothos that spelling was Writun or Oral

XVII. A Tabuletion Comparing the souree of speling Words as Indleated by the 255 College Freahmen and 25 teachers of High-behool sentor mglieh by Truber and Rer Cont

XVIII. A Tabulation by Irwiber and Por Cont Cowparing Anewers of 155 colloge Froshen to Anewors of 25 Tonoher of H1gh-sohool sentor Inglish Concerning that Was Done About Mrepelzed Worda

xIx. A Tabulation by Wubor and Por Cent Comparing Anmwere of 155 College Froshmen to Anwwers of 25 Teachows of High-eohool sentor Inglioh ae to Whothor studente Had spelling Hatohos

XX. I rabulattan by Inuber and Por ceat Comparing Ancwern of 155 College Freshmen to Answors of 25 tewhors of High-ahool sentor Baglith Coneeraing Whother They studied Words that Had Been Misepelied In Thomes 
XXI. A Tabmiation by Iumbor and Por Cant Comparing

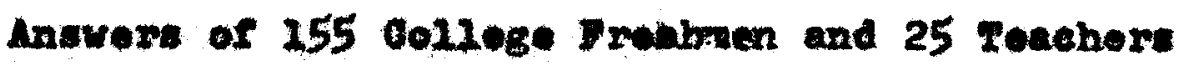
of High-eohool sonior Buglinh Comoeralng Treining in Voobulary in melf th opade

XXII. A Tabulation by Number and Per Oent Comparins Answere of 155 College Freshuen to snewerw of 25 reachers of High-acheol sentor mgliah Regarding Awount of Time Spent in the study of Ilterature

XxIII. A rabuletion Comparing Antwer of 155 College Prosbuen to Anewere of 25 Teachera of Highsohool Sentor Bngliah Coneerning Other Courses if anj raken with Litorature, By number and Per Cent

XIV. A rabulation Compering by Iumber and For cent the Answere of the 255 College Freshen to the Anawers of 25 Teachera of High-achool sentor Fnglloh Rogarding what their study of Sentor High-echool arawn: Inoluded

XXV. I rabulation, By Irmber and Pow Oont, Showing How Orten these 155 Gollege Prowben Indloated They Studied Gramay in High-sohool sentor Engliah Compared to How Often the 25 Teachore Indieated they taught Gramas 
XxVI. A Tabulation by Irmber and Per Cont showing what Was Done in fiemedial Roading as Indicated by Answers of the 255 College Areshmen Compared to Answers of the 25 reaehore of High-sohnol Bentor Inglien in Loulevilie and Jarferwon County

XxVII. I rabulation by trumber and Per Cent showing Anewere of 155 Colloge Proahmen Compared to 25 Feabhers of Figh-eohool sentor Finglieh Oonoerning whethor Examinatione Wore Admin1:tered in High-echool sentor English.

XXVIII. A rabuintion by Number and Per Gent Showing that Type of zamination Were Adminlatered as Indloated by the knwwers of 155 College Freshnen and Compered to Antwer of 25 renchors of Highsohool sentor migliah

xxIx. A Tabulation by Eumber and Per Cent Comparing How Orten Etaninatione Were Meministered as Ind 1eated by Anewere of 155 College Frenbmon and 25 Teachers of High-sohool Bentor Iagliah

xox. A Tabulation Showing By Fuber and Por Oent Whon Exmination Papors Wore Roturned as Indiosted by Responses of 155 College Freahmon Compared to Responess of 25 Toachers of Elgh-school Sentor Inglish 
XxxI. A Comparison of the Roupones of the 155 college Proshmon Concerning what Finaliy Became of Braminetion Papere with the Responses of 25 Teachers of High School sentor Englin. Tabulated by Number and Fer Cent

XxxII. A Tabulation Showing How Howe Roading Wa: seloctod as Indionted by 155 Colloge Frenhmen and 25 reachers of HIgh-nohool Sentor Bnglieh, Tebulated by Number and Per cent

XxxIII. A Tebulation showing How Students Wore Requl red To Report on Reading Done Outside of Cy as in H1gh-sohool Senior Figlioh as Indicatod by 155 Colloge Froshmen and Compared to Hothods Teachore of Flgh-echool Bagliah Indionted They Required

xxIV. A Tabuletion Comparing Itens Cheoked by 155 College Freshmen Ooneerning Motivation that Beouraged Them to Read in HIgh-wehool Senior Engliah to Item Oheeked by Teachers Who raught High-wohool santor mglish, by rumbor and Por Cent 
OEIPRE 1

Statement of the Problen 
OAnPTER I

ImrRoDUer ION

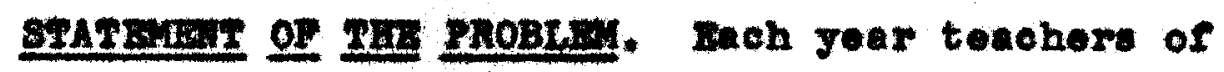
Bnglieh and other whool people are beocuing Incrousingly coneornod about tho attempt of atudente to more from highsohool to colloge Bngliah with the least poselble alfrioulty. And wach jear these teachers and sohool peoplo set about trylng to do vomothing obout the atuation, oach in hio own way. College towohors and high wohool teacher of, nalieh have the same najor objectives in wind. Tholr concern is whother the one can ecolinge the training the othor utarted with the least posulble break.

Eututore ere oonoerned about the poor artleulation among grades of the syotem. There is lack of olarity as to oach grade'g function in relation to better oommunleation. The defeets are nost prominent porbaps as the otudent moves from high shool to oolloge. This condition Imposes wasteful repetition ad nakes for laek of continulty. High-ebhool teachers of raglish want to know what comprisos the proper proparation of thel studente for oellege Iaglimh. They want to propare tholr atudente vo that they cen salily adfult at the oollege of thelr oholoe. In faot ano toagherm have wald that they and their contere aro so bus reviowing gramer that there is no time lort for teakhing writing and reading thomes. 
College roachers of Faglieh say that studegta nod adequate preparation, but they do not agree soneerning the best wothod of soouring 1t. The colloges attompt to give the best odveation possible within tholf meane. They face

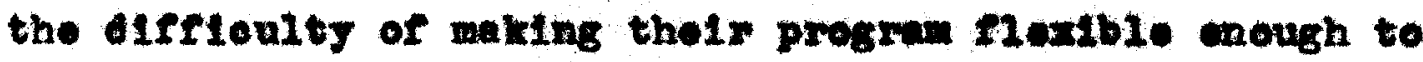
aceomodete the wide difforonees of ability, Intereet, and meturity of thoir atudonts. As in the high sobool, tholr program is almowt Inoritably goared to mot the nowit of the average atudent. Special attention is given to the poorer student, while the ablez tudent remalns the viotin. Thoir abliltios must be ohallenged or thelr intorests in learning wanes.

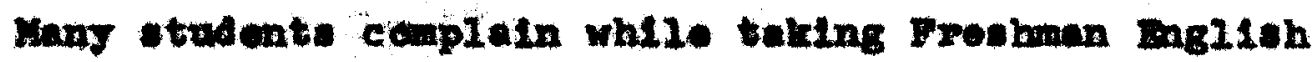
that they never oovered a particulax phaee of "gramar" whioh they find diffioult of that thels Buglish teacher took an ontirely asfrerent approach. Mang way they otudiod moohanlos but wore not rupulred to write to put into prastios

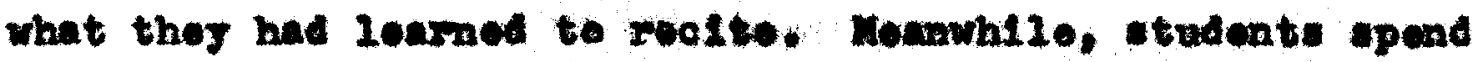
valuable colloge time romolithg dofteleneles while othore waste time dupliaating whet thes alroedy know. The abzor studente seom to oufror most.

This etudy was made in an attempt to diseover what

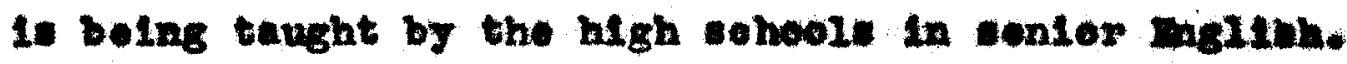
Perhape by finding out what the teachow taught as wo. I a what the students as thoy were taught, some insight that

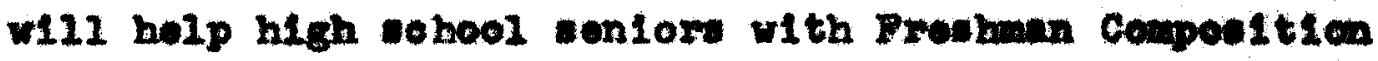
might bo galnod. 
Paxhaps the dealros of teachers of high sobool

Diglish w11l be atimulated to moet with toacher of oollege Malleh and plan some derinite progran that will holp students move from high sohool to colloge Inglish with the 1east possible edjuttient. The purpose of this paper was to ocmpare the atatemente of 155 college freabmen at the Onlvereity of Loulavi21e to the otatemeats of 25 teachore

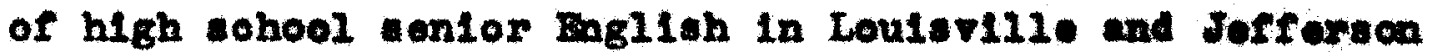
County. Kontuoky. consoming what was taught in high sobool eonior anglish.

EPPOTHPSIs. The tudents' oonoept of toplos covered

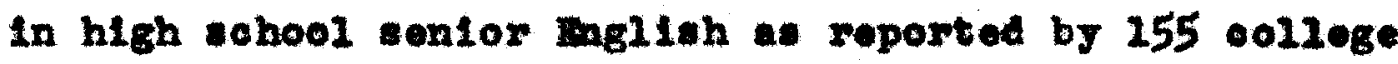
freshmen will be the uane as the conoept the teachore of high sehool conlor Daglish hold conoerming what they taught.

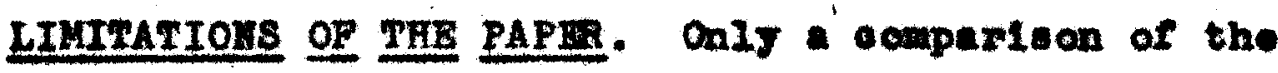
reuponses of atudents and teschore conoerning what was taught in high wohool sentor anglioh was considered in this atudy. Whother or not what these students studied in high

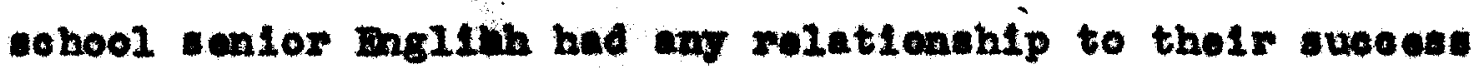
ox rallure in Frombun Componitien in $00120 \mathrm{~g}$ wovld make an Intereating atudy in 1teolf. However, the writer roelized that this papor mut bo IImited to the studente' and tenohere' oonopt concerning whet was taught in high wohoel entor Inglioh rethor then brenohing out in too wang derotion. 
CHAPTEA II

A Reviou of Bom Litoriture Related

To the Problea 
A REVIZ OP SOME LITEATTUE RELATED TO THE PROBLE

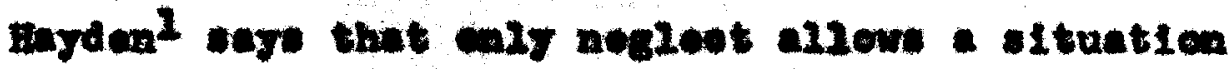
to develog in whioh atudente errive it the eallege lovel co 111-propared. In on effort to improve thit altutica, he euggeats that teachers start with condition as thy are

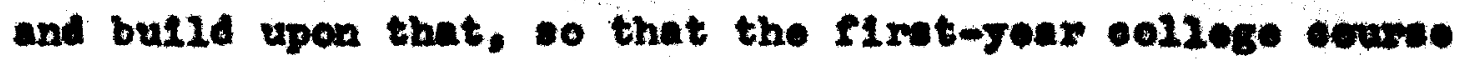
In Bnglieh or oommonioution will smong other objestivos carry on the wan work the high sohoole have bogm. What orrore in reading, in writting, and in thinkting to the student: nake? Ho augeate that inglin toashors ohould attompt to improve roal condition rathor than think of melish as an ldoal Imgange to be taught. Inotead of weleot-

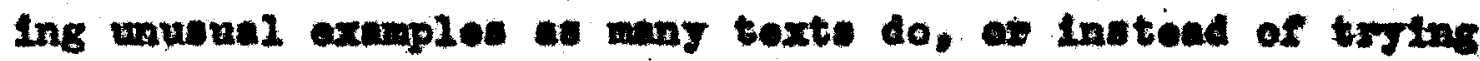
to teach rine pointe of gxwmar, teachore ohould attak probieas in the atudente' writing. What atudente atudy in grammer hovld aries atturally out of oommenleation noeds. Thofr study of high ooheol mglish ohould bo a proparatien not an anticipation. 2

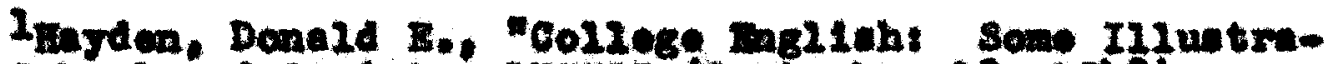

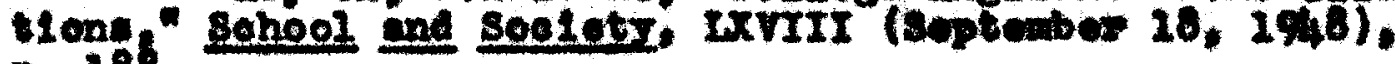
p. 188.

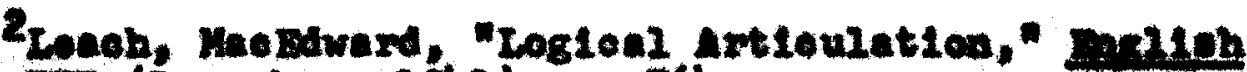
doventy xa (torombor, 1941). p. 764. 
There is a need for more olosely integrated mglish program from the earllest grades to college. Time is lont In duplioation when it is unneseseary and in not dupliostIng when it is necessary. Invtead of trylng to toach orerybody overgbody' errorw, epeetal amphanle should bo plaed on the repeated errors of each otudent. This would mean more Indiridual Instruotion and lass gonorallention frow toxtbooks. A I1ghter pup1l loed por toncher would be nocessary. In this way the teacher would hare the propor time for Invtructing oach pupll as to the correction of hil own orrors, thus making "gramme" more moaningtul to him in his om pertioular altuation. 3

There is ow Indleation that colloge coureses are belng adjuted to high sohool beakgrounde of students now, howerer. In consequence fower frosben oneounter oxcesal ive orerlappling and duplioation of content as they nove from hlgh achool to celloge ocures in the same rleld.4

Adequete oowndeation between oollege and high sohoel teachere help break down profullees and misoonoeptions. V1s1ts to the high ahools by nubers of the o01lege faevity are being encouraged. Also conweranes between high sohool and oollege teachere to diacuas theif matud problem can uneoril some raluable Inforwatlon. Mng wolutlons can be

3rarden, ge. 01t.. p. 188.

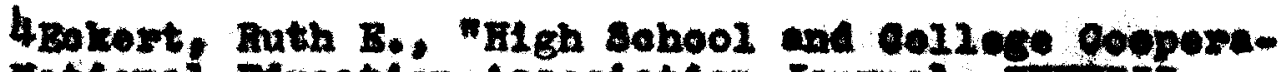

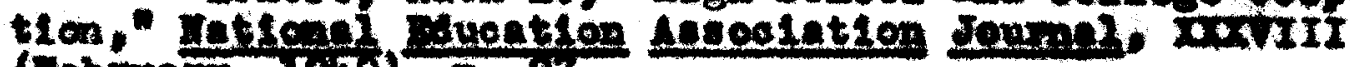
(Yobruary, 1949$), 5.97$. 
reached by the removel of the high sohool and of the college from the isolation and raootw in which oach hes worked in the past. 5

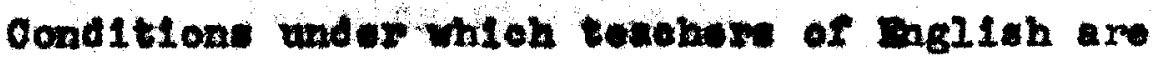
expeoted to glve trainting in exprovilioa have been altered greatly. The total effect of those altared oondition is that people must be more oxpressive. Ohenge in iteelf, protuces more convorwation, more explenetion, wore als. cunslans, probubly more writing and more liatening. In apite of these oranging oondition, the edministratore and

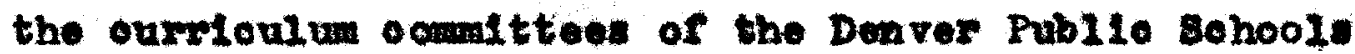
found whon they looked olosely at the total Inglinh progran throughout the agotes that the program, all a wole, had

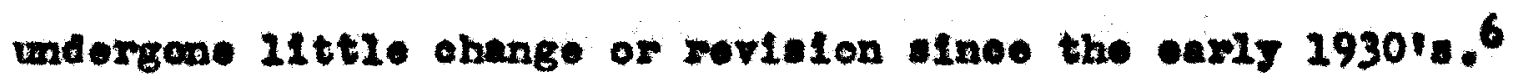
can wuch a progren prove adequater

Tho high wohools have ralled in the teaching of writing. Ingliah teachere in high school have taught "graman" hopteg in acwe way that it would rorloot 1 tuale

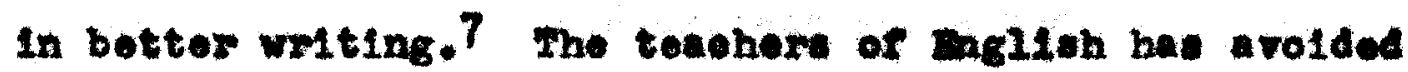
having puplis wrte-crrequently and parposefwily. The

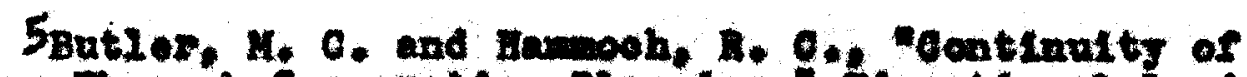

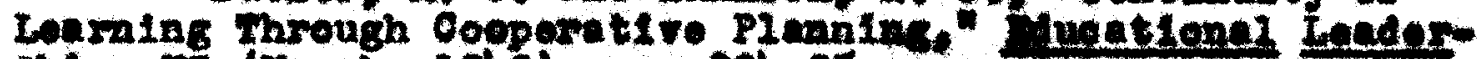
Lis, in (narsh, 1949), pp. 394-95.

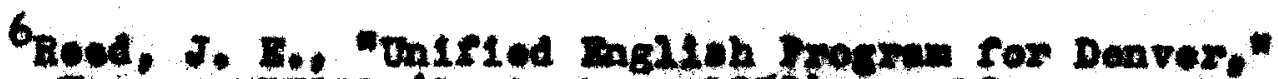

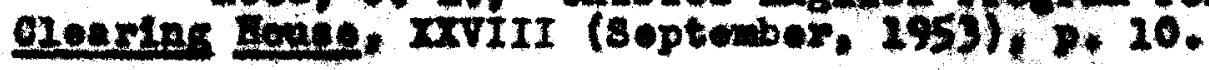

7MI1, Barmis, "Migh Sohool Graduate and Golloge nglish, sobool and soeletr. LxI (Pobmany 28, 1950), p.104. 
rolatively mall amount of writing done in sow high sohoele 1. an Important factor in asalgmment of 2 axge numbers of oollege freahmen to rumedial work. skills in writing come with preot1ee. Leaming to wite is a matter of grouth that mut be oypathotioally and onveruing guided over a long perlod of time. 9

Practioe in writing is neglected becewe the

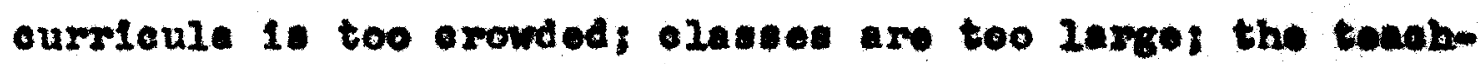
Ing lond it too heary. Teachors are appalled at the prodpeet of roaling alzobble amounts of student writing exitically and ayopethoticeliy. Instead thoy seck the showter mothod, dr111: and examinationt.

Tenchore of Paglioh have falled to make writting purposerul, meaningful, and Interesting to the studente. Artiflelel sealgnments are glven, woh as "thomes," The duel function of student writing is aelf-expreesion and comaniogtion about thinge of interest to the uriter. 10 No teohniquea will be particulang ovooserul uniose tho

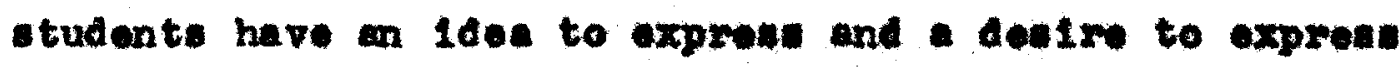
$1+21$

8stowart s, Horgan, Ohalman, st. Al. "Integration

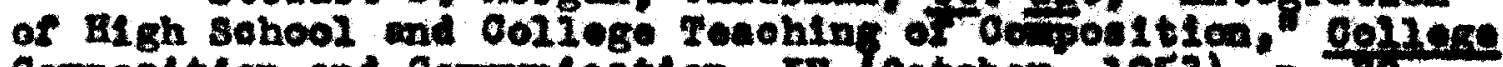
Composition and Compinioation, iv (ootobor, 1953), p. 79*

90romon, Alfred H. "Proparing High-Bohool student:

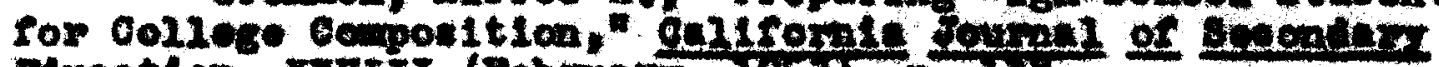
Eueation. xirII (Pobruery. 1953). p. 16. 10.1218, og. e1t.. p. 204.

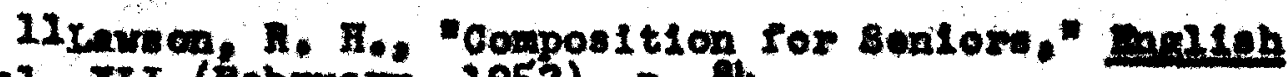
Jenred, XII (Fobranxy, 1952), P. 84. 
Knowledge doos not guaranted corroetroas and ozenty in writing. Knowledge does not touoh on olarity of prupose, effoetive leleation and amongoment of material and foreofulness of expreselen. extmar is dowotimes taught as if all gramer rules and prinolplos were of equal Importanoe in achleving olarity and correotnesa. Nore w111 be aooompm lishod if tequhors mark as most important those errore that arfouly interfore with the najor purpose of writing. Onintentional sentence-rragmenta, rallure of igreament between subjoet and verb and pronoun and anteoedent, alsused aprostrophe, and wrong form of verb and pronoun are a fow of tho grose errors. Those ean be taught alreotly and uned with suceose if oloarly 111 wotrated and related to dynamio pattern of Ingliah usage. Studonte noed to be sow that gramen 18 far more than attor of gramar and meohanios, that oertain major aspoots mat be dosit with when they get out of hand. In this way the student morale w111 be better, and he oan work progreasirely with hope. 12 students hould write at leavt once crery two rookn. Short papers witten fraquently are botter preetice than writing long papors ocenelonally. Nost papers abould be written in alase. Of course, thorough properation mutt precede the aetual writing of the peper. Oesastonally impromptu thomes in elass are most helprul, oupoeially 
near the beginning of the term. These thomen give the teacher some tenglble soure frow which to deterwine the needs of the atudent. 13

Tonchere are outtlonod egalnet morely prodroading the pup11: paper, a fault that of mang toacher of Englioh cannot dony. The tudent'a primary interest would be to communioate; and when he has been tom lapart ones, ho is

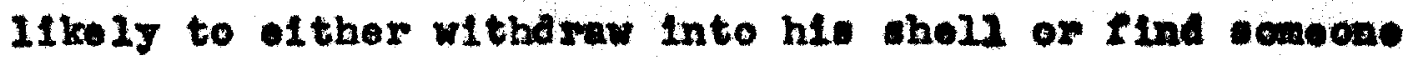
180 whe aen be more epproolative of his orforts. I4

There 10 more reading of orery art going on today then ever before.15 Provide reason for reading, and otudente w11I read. Toubors oan aroate an Interest to whioh roading oan contribute, making roading a moans rathor then an ond. Ho book is dull or utelose if a person likes or wents it; however, everyane does not have to 11ke the same books. I ploce of Ilterature may be Importent and groat for differont poople and for the same perwon at different stages of his 11fo. Woahan10e or optical instruments should not be depended on to solve roading problewa. Helen Keller hes soid a library of books. A destro neede rinet to be orented, 26

130 roumon, ge. 01t., p. 125. 14.101e.. p. 116 .

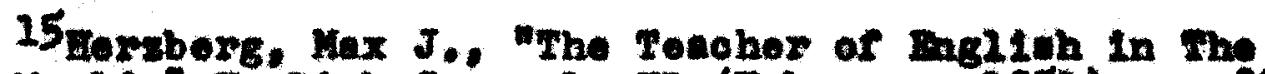

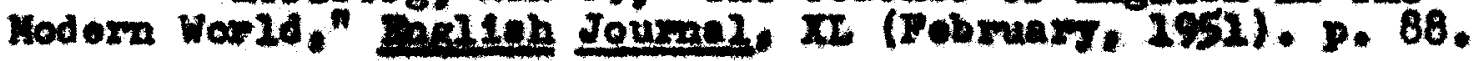
16 ro1d... p. 89. 
Bools should not be rogarded as the sole modium of reading. Hewapapere, cooking recipos, and mitting diroetIons are reading, too. Bf encoureging the reading of verlous thingw, teachore make reading a pleasure, Feading

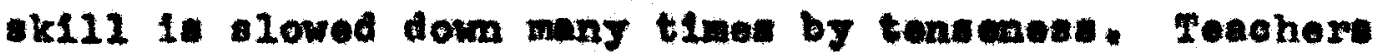
woh show that reading is Indisponsable. The builness of al teacher in all subjeots is to tonch reading, but Ingliah tosohere bettor not expoet many of thow to do so mleas thoy are looking for dissappointwents, 17

The proper plecement of students makes for botter ad justed tudonts. Placoment, however, 1s not the moohnnieal sorting of individuala with olmilar charmoteristios into groupa. Placement is louming exparlenoe, a mothod of helping the student soe his orm needs and of furthor dovelopIng hil ablilties. Bach student should be pleoed on texporary bas 10,18

Many oollegea elmply "separate the sheop frow the goata" so to "pak and plece those who made an inforiar score on the ontrance oxantnation in non-erodit Inglieh coume. byeter 19 foels that at Namen 0ollege, Marion. Virginia, a plan has been diseovered that worke to a gronter adrentage for them. The Ingliah Dopertmont doefoed that a remodial oourse In Inglioh failed to bring the denlyed

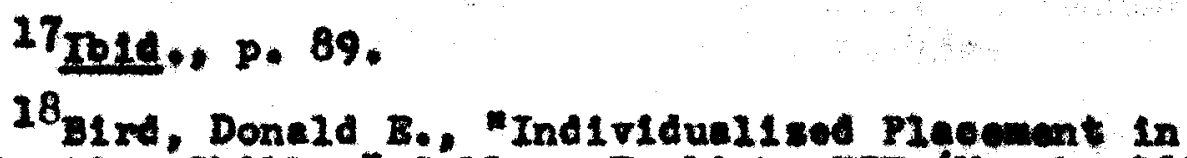

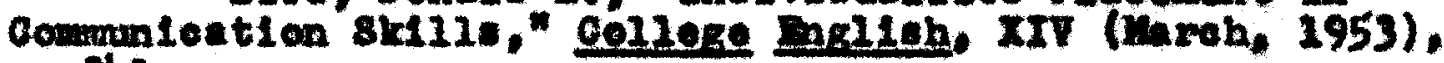
p. 341.

\section{9}

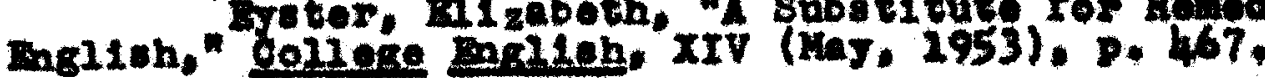


results. They found that the romodial course without oredit Ine reases resentment.

Since the students who aw in nod of rewedial eourse aro, Invariably, thoes the rute at alxth- end seventh-grade

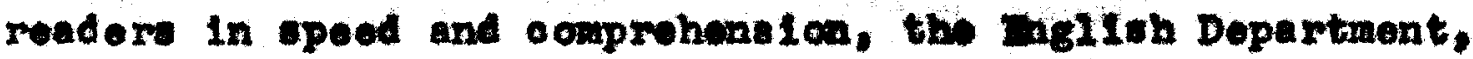
deolded to subetitute oourse in chilerents IIterature given for crodit. This ooure integrates wil with the

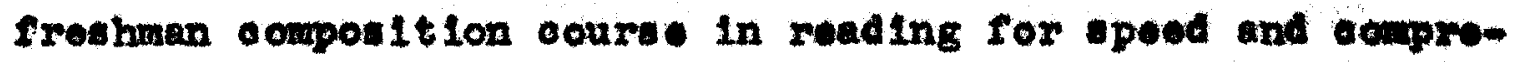
honelon, eraluation of literature, oral prosentation, and vritten woric. 20

As 1de from roading and writing our modem world expeots teachare of Pnglish to give joung poople due understanding of the now moditus of ocmunisation in whioh worde are to a grater or a less extent involved. Buglish toachere are apparentij expeoted to take hand in the eatablismont of cound oriteria for the movio, radio, teieviation, porhapa the oomios and pleture magasines as vel2. Wa1ker2l adwoniahes teachorw to keep in wind the great purpose of a demoeraey-m that sach person is through the schoole, to have acoess to on opportinity to learn a Ianguage whioh will not handioap him in finding his proper pleve in soototy.

\section{Ib12: p. 467 .}

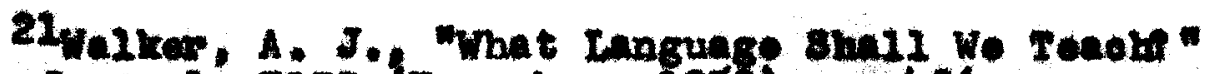
Eglieh Jonzal; XIII (novomber, 1953), p. 436. 
Rogular drillo on voeabulary are most helpful in assisting atudent to clarify theix underetending of worde they alrendy une. In addition each studont hould add say flro new worde oach wook from roding and other sources. Sone agreoment should be molhed on minlmus oseentiale to be given apedial attention luming the joar. Those abould be establiabod on the basis of cownomioation nood in eentext wth experionce as shown by error in thomes and othor writings. 22

Vocabulary atudy comnot bo cuecosefully carrled on by the Inglish teachere alone. Irow teacher should be lert to 1t: Importance and hould teach the roobulary of

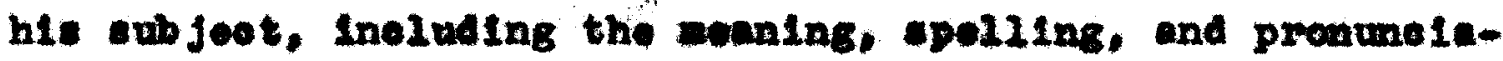
tion of words. 23

studente read, write, or tudy rocabulary if an interest is orested that makes sense to them. Porry ${ }^{24}$ refere to the etudy of Brumer, Postman, and Holinnie who explored the relationshlp betweon person's values and his skill. People were found to require loss time to rooggni wo words thay like and longer to reoognizo words they do not 11ke. Even the studenta' resiatance is not

\section{Ible. P. 117.}

230urkes, Frod, competenes in Nuglish in Axtioulation PIan," Cloarins Bouae, IxV (November, 1950). p. 149.

24 Perry, William 0., Jx.. "whe 600-Werd theme and

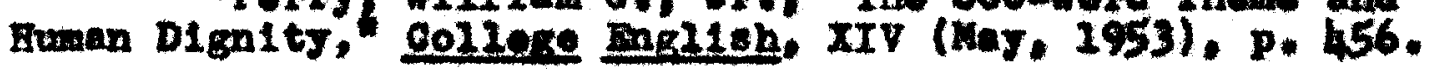


fatel he euggeste unless fought by the teacher. If 600 words ls not sot as must for aper, students do not mind ao much dereloping the ubjeot rather then counting worde and reeling honor boand to welte a certain number of woxda. Workenop 12 of the 000025 wonderw whother language exerolses might be orowling out of composition opurses the actual writing of papere and aotual opmunieation. They agreod that language atudy 1s a moans toward the improvement of oomminication and not an ond in 1tself. Walker 26 rominded teachers of Inglioh that achlovemont of the goal is not so important as thet the atudent when he leaves the olase In aware of the goul and has the moans and the desire to continne to etrive toware 1 t.

25stowart 8. Horgan, Ohalman, at. al.. "Integration or High school and colloge reaching of Gowposit ion," golleme gomponition end commiention. IV (0otober, 1953). D. $\%$.

26.1kalker, on. e1t.. p. 448 . 
CEAPTER III

Wothed ond Bubjecto 
Eaterte21. I quoutionnaire. What You studied in Hlgh-Behool senter belieh, wa devined for the purpose of this sudy. The quostionnalre was propared in an attompt to determine what atudents enrolled for frowman Dolioh at the Unireraity of Loulerizle thought they atudied in high-wohool wenlor Baglish.

The questionnalre contalned eleven parte: (2) Written Work; (2) Grading and Revising of Thomos: (3) speling) (4) Vocabulary: (5) Literature; (6) Orammar; (7) Remedial Roading: (8) Dxaminations (9) Hom Roading; (10) Diffioultios: (12) Buggostions. A copy was inoluded in tho appondix.

8ub 1eats. The anbjoote uned in this atudy were 155 atudonts arbiled for freshmen Inglieh, the ont1re number who happened to bo in the ovetleas of English Compoition ohosen at random, and twasty-rive teashor of highmohool senior Ingilah from Loulavits and Jefferwon County. Kontuokg.

Information from the rost Burean recorde at the tonivermity of Loulevil1e Indiented that 203 of the 359 college Ireshnen aurvezed at the Onlverelty or Loulevilie for rnglioh otudied in their centor joar of high oohool 
came from vohoole within the ofty of Louleville. Bightyfive of the freshnen came from county high sohoole or sohoole out in the state. sixty-nine of the freshmon

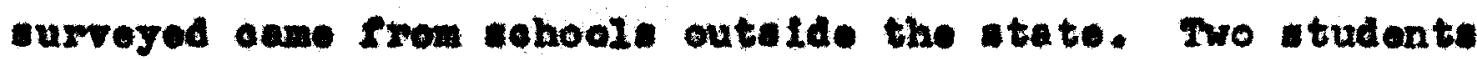
oume from Kontuek Mi1tary Inat1tute.

From the etudente' rocords also was taken and rooorded In table form the ages of the studenta as of $\mathrm{Hay} 1,1953$. total peroent1le wcores of owh student on the Pajeholoss. the Mglish, and the General Culture Teats. The seores were part of the scores recolved on the general hehlevemont Test given the freabmen as entrano requiremente at the university or Loulevilio.

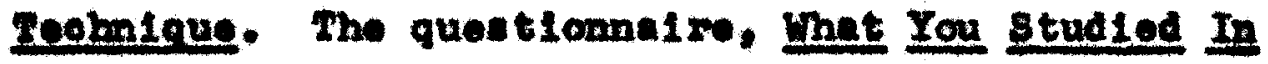
High-sohool Senlor Baliah, wa adminiatered to the subjooto

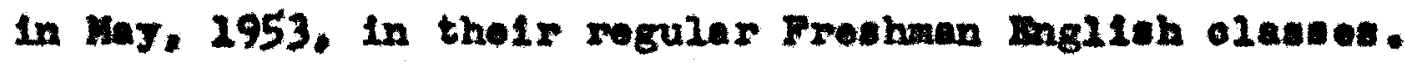
Ho named were afflxed to the questlonnalres. The atudents were albed to anawer the queation trathrulig and as o completely as poasiblo.

The quedtcandires wore edninietered to the tesohore of high-sohool senlor Bnglieb at the wohool in whteh he or the tevight in May. 1953. Bom of the teachors f1110d in the questionnalre immediately! while othere asked to have time to complete thon. Those were soturned by mall upon couplotion. 
OANPW IV

Berertption of the subjesto 


\section{DEsORIPTIOI OF THE SUBJBOTS}

A tobulation of the egen of nembers of the frochwan clase whioh we survered for tnowledge of Ingliah tanght In the sentor year of high wohool was shove in rable $I$. The range in age of thle group was from 16 reare and 10 monthe to 45 jears. The median age wa 18 joam and 10 wonths, and the moan age was 19 jears and 10.77 weath wth a tendard deviation of 36.78 .

\section{(Beo Page 20a)}

Tho ago distribution was not normal. About 49 por cent of the elaes was hown to be of the expected age lorel for college froshmen, the expected age belng 18 yours and 4 montho to 29 joars and 3 monthe of Ning 1 of the cohool yeas. The tabulation showed 120 of the 359 frockmen as older then the expected age for college Iroshmen. One of the studente wa 45 joars of age. There were elx atudents. above thitty yeare of age in this group. This was probabiy wo to the faot that veterans wore roturning to aohool arter eorving in the armad forwes. Sixty-one of the students in the group were jounger than the expested age of college froubuen.

The peroont1l wooven for the group of 359 oolloge

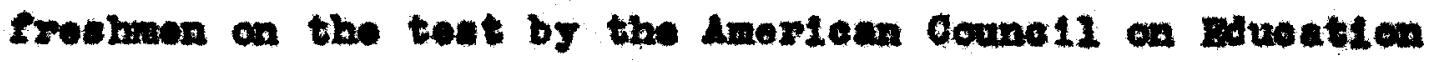




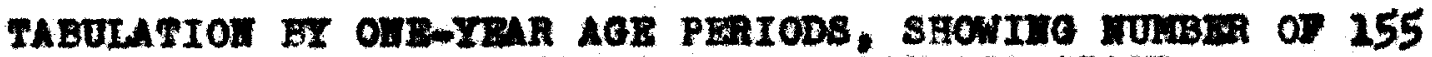
OOLLDOE FRESHAE IN BACH ACE OROUP

Cronologloal Ages"

$26-4-27-3$

$27-4-18-3$

$18-4-19-3$

$19-4-20-3$

$20-4-22-3$

$21-4-22-3$

$22-4-23-3$

$23-4-24-3$

$24-4-25-3$

25-4 - 26-3

$26-4-27-3$

$27-4-28-3$

$28-4-29-3$

$29-4-30-3$

$30-4-31-3$

$31-4-32-3$

$32-4-33-3$

$33-4-34-3$

$34-4-35-3$

$35-4-36-3$

$36+4-37-3$

$37-4-30-3$

$-45$
Tumber Froahnes

7

54

288

35

12

9

15

22

9

5

2

3

3

0

0

2

1

0

-

0

2

a

1

rotal

359 
Payohologleal Examination ${ }^{1}$ was shown in Table II. whe purpose of this examination wal to appraite sobolastle aptitude of general inteli1genoe with apeolal referenee to the requiremonte of most $00210 \mathrm{ge}$ ourrioula. The Quantitative and Linguletio soores whioh were avallable ware not used, The ceeres ranged from 0 to the 99th porentile.

\section{TABLE II}

A TABULATIOH SHOWInO THE TOWAL PAYOHOLOCX BCORBS OF 359

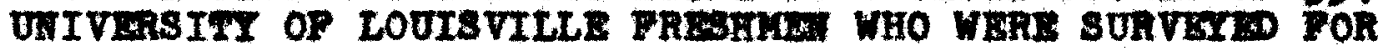

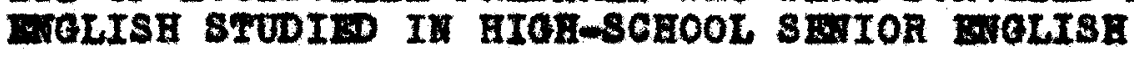

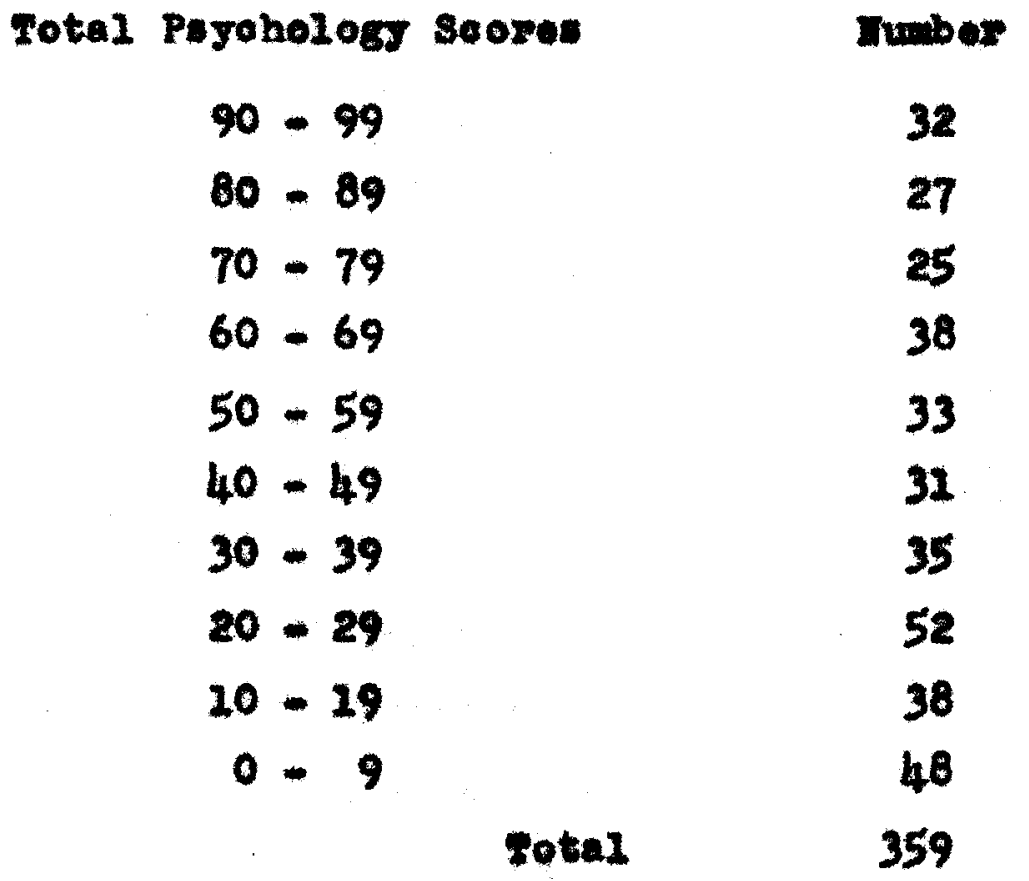

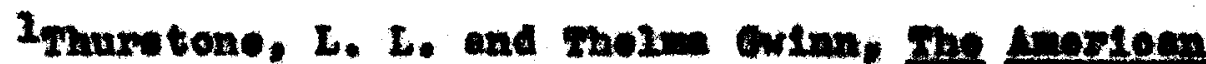

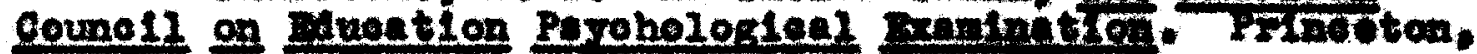

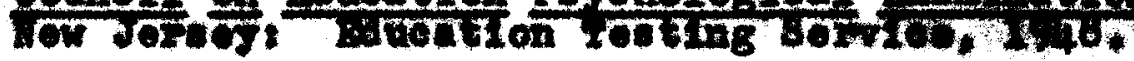


The modian percent110 ceore wa 41.50 . The moan porcent12e seore was 44.88 with a tandard dovietion of 28.45. Thil soew to indicate that the growp wore of normal Intolligenes and eapabio of folng arerage work rogutrot of ólloge trestuen.

The midale one-thine or the elade seoned botwoen 27 and the 65th porecntiles the upper ono-thir of the olese woored botireen 65 and the 99th percent120. The lower anew thir soored between o and the 27th peroent110. Ports. -1ght students from the group soered from 0 to the $46 \mathrm{~h}$. peroent110. The diatribution of the teat soors alfroped algnifleantly frem the expected boores, at the expocted number wa 35.9 in eneh deolle. Foxty-e1ght, wore then the expeoted numbor of 359 college frobhen, coored from

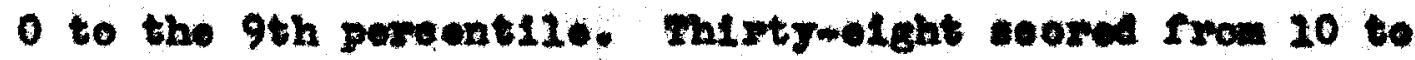
the 19th pexoent1l\%, this aleo belng noxe than the expested number. In the dec1le frem 20 to the 29th pereent120 52 weored, more thin the expooted number.

Dewer than the expeoted number ranked in each eategory from 30 to the 99th poreentlie with one exeption, this bolng the oategory fwow 60 to the 69 th peroentile which had 38 atudente. Thirby-ane seored fram 40 to the 49 th peroentile. Thirty-five otudents seored botween 30 and the 39 th pervent12, 31 between 40 and the 49 th peraent11e, and 33

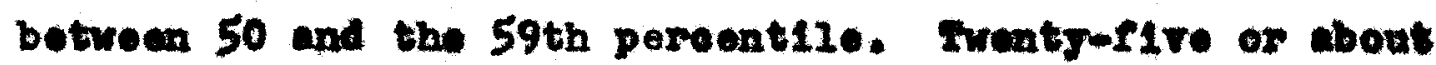
two-thirde of the expected number seored betwew 70 and the 79th popeentile. Iuenty-erven seored between 60 and the

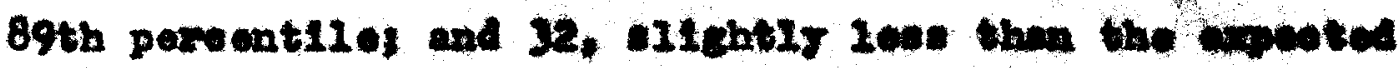


number, soored in the eategory fros 90 to the 99 th perentile.

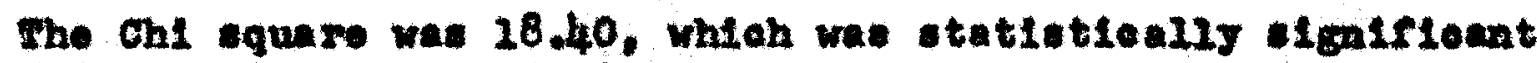
at the 5 per oent lerel.

Table III thewed the aeored of the 359 colloge rreah-

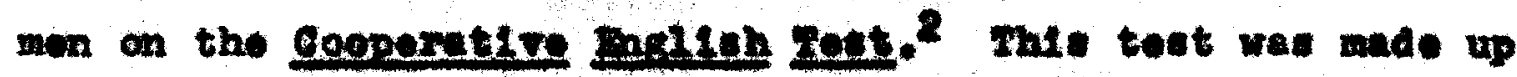
of three sub-teate concerned with Heohmies of Bupresulon. Eefeotiveness of Expreasion, and Rending Comprobenetion, et ther one of whleh could have been ueed alene, Thie makes poselble the determining of whother the Indiridual's grateost need is to Improve his hablte of unage, or to dorelop greater akill in orgenialng mterinl and prosenting it effoctively in writing. The total teat weore was wed in this atudy. The coores ranged frew o to the 99th poroent120.

\section{ADLE III}

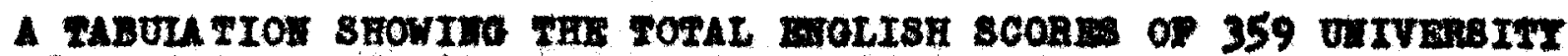

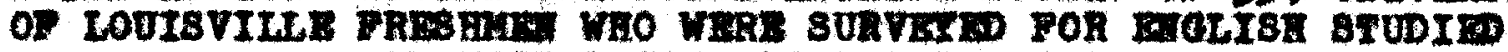
IT EIOR-SCHOOL SEIOR ENOLTBH

Total English soores

$$
\begin{array}{r}
90-99 \\
80-89 \\
70-79 \\
60-69 \\
50-59 \\
40-49 \\
30-39 \\
20-29 \\
10-19 \\
0-9
\end{array}
$$

Number

I4

25

27

20

37

29

49

40

53

75

359

sotel 
The modien pereontilo woore for thit group of froshmon was 30.70 . The mea pereontize ceore wae 35.48 with a etendand deriation of 26.59 . This indloated a bolow average group in the eomprohmetex of aral on written Inglish. The weale cno-thind of the growp neored between the ceores of 15 and the 45 th pereent11/ the uppor one-thim or the olase soored botween 45 and the $99 \mathrm{~h}$ peroent110. The lower one-thind soored botween 0 and the 15th pewtentlle. Only 29 tudente seored above the 80 th pereentile. This number was only .08 por cent of the total number who took the tost. Oror ons-this of the group soored below the 19th pereent11e.

The distmbution of the teat aeopes differed from the expected woored, as the expeoted number was 35.9 in eell dee11e. There were 75 or the 359 co110ge frouhnen who soored betweon 0 and the 9th pareent1le, orer twied the expeeted number. Fifty-three soored between 10 and the I0th peroent110. Forty soored between 20 and the 29th peroent1les and 49 soorod between 30 and the 39 th pereent110.

Pewer than the expected number of atudents ranked in eaeh cutogory from 40 to the 99th poroent11e. There wero 29 In the oategory from 40 to the 49 th poroentile, 37 from 50 to the 59th percent12, 15 from 60 to the ogth porwent12. and If from 90 to the 99th peroent11. Only 29 atudente soored in the upper two ontegortes. The ont equare was 
90.10, which was signiflemat et the 1 por oont lovel and Indiented that the group ourveyed differed elgnificantiy from the nomul group.

The gonerel gultuxe 20at ${ }^{3}$ by the Rducetion Festing Sorvice consiats of Sive 30 matnute sections: HIstory and Soo1el Studies, Literature, seioneo, Fine Arte, and Mathomat10s. The content was arranged to thet any couree a student had had in one of the areas mabled him to mowor aome of the questione in that part of the teat. The totel cohleroment scores, whleh wore uned in this etudy, were totals of 1 the sub-tests.

The total scoses of the group of 359 college rroshmen from whioh the aurver wes made to deterratine Bagilsh taught in the entor yoar of high sohool were shown in rable IV. These coores ranged from 02 to the 93 rd pereentile.

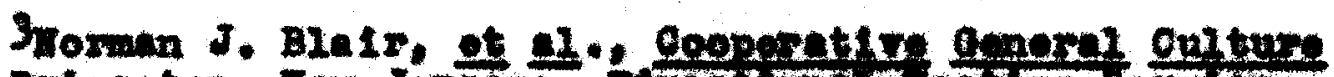

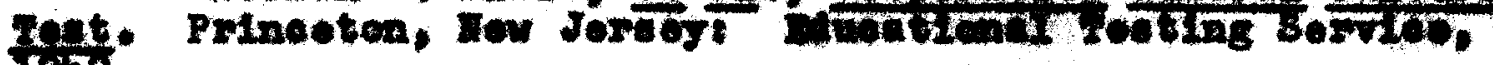
1949. 


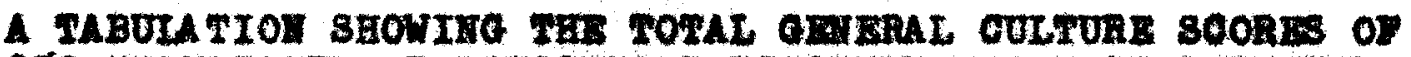

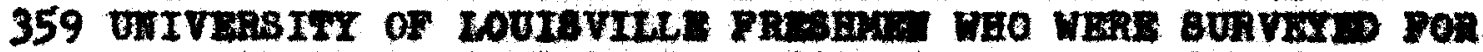

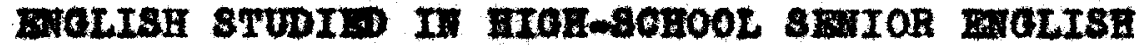

Total Genoral oul ture seoven

$\begin{array}{ll}90-99 & 7 \\ 80-89 & 16 \\ 70-79 & 22 \\ 60-69 & 25 \\ 50-59 & 26 \\ 40-49 & 34 \\ 30-39 & 36 \\ 20-29 & 54 \\ 10-19 & 58 \\ 0-9 & 81\end{array}$

Sotal number

7

16

22

5

359

The modian poroentile soore was 26.20 . Tho man peroent110 weowe wa: 33.78 wth a tenderd doviatiga of 25.70. This Indiented bolow the now group in aohlore. ment in aplte of the frot thet tholf abli1ty to learn was arerage.

The middle une-thl we of the group cooxed between 17 and the find percent11. The upper onothird seored botwem

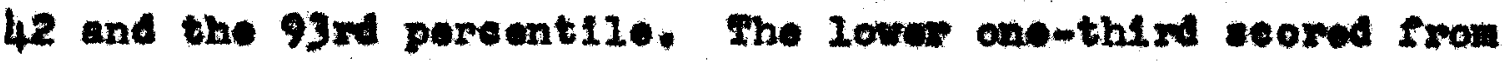


O to the 17th pereontile. Hghty-one of the 359 a tudate ceosed botween 0 and the 9 th preont1le.

The diatributien of the cooros on the Geperel galtax.

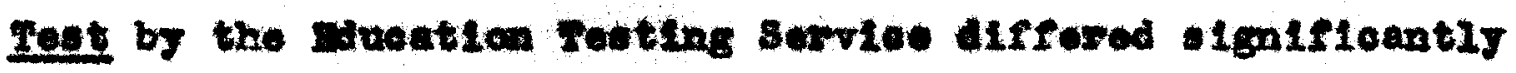
fron the expected atribution of 35.9 in sech coallo. There were more then the expeeted nwober botwen 0 and the

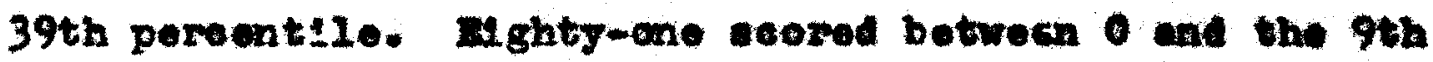
percent12, 58 seoned botween 10 and the $19 t \mathrm{th}$ percentiles and 36 seored rrom 30 to the 39 th pexcentile.

In owh category from 40 to the 99 th powontile fowor than the expeoted number sooxw. Thirty-four soored between 40 and the 49 th peroentiles 26 soored botween 50 and the 59 th pereentile; 25 cooxed botween 60 and the 69 th percentslos 22 acored betwem 70 and the 79 th pereentiles 16 soored betweon 80 and the 89th peroentile; and 7 seored botween 90 and the 99th percent1lo. In Table IV the higher the soore, the fowor the atwents ranking in each eategory. The ohl

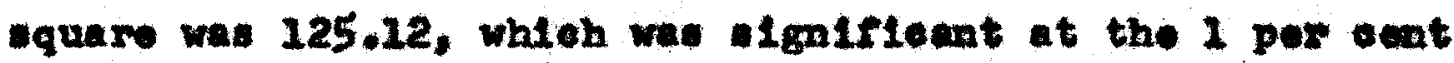
1erel, and Indicated that this group of studenta differed signifleantiy from the nowal group.

Two hundrod throe of the 359 oollage trobkmen ourveyod at the Dniveraity of Loulavilie for Dalinh studied in thelr wentor your of high achool owme rrom schools within the olty of Louferille. Bighty-five of the froshnon oume from eaunty sohools or sohools in the state. 81xty-nine of the froshmen eurveyed came from sohoole outeles the etete. Two studente ame rrom Ientuck Miltary Inatitute. 
The frobhmen ooning frea differont obools in the otate and outalde the otste probably would reoult in wow rarlety in thelr study of agelish in enlor high-oohool. Many of the wohoele bave tuglteh ol woted with speolel

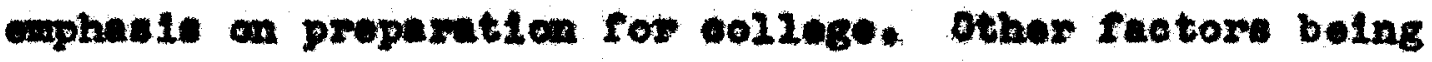
equal those atudents should have ace thoworgh mowledge of the rundamental than tudent: who wore taught without anj thought of meoting oolloge atanderde. some of the high ochools probubly have cnly one oless of hlgh-behool senter Ingleh whioh wat moot the needs of all the students, a tromendow undertaking for ay one lase. 


\section{OEAPTER V}

Vutten Vork in the roaking of

High sobool sentor Englith 
WRITEE WORK IN THB TEACHINO OP HIOH SOEOOL SEIOA EHOLISA

Ianguage atudy ahoula bo nowa toward the improvo-

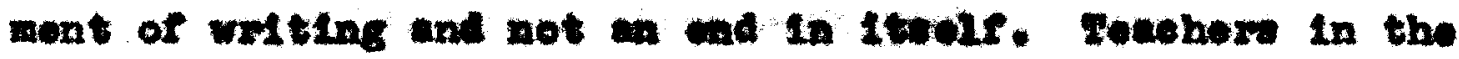

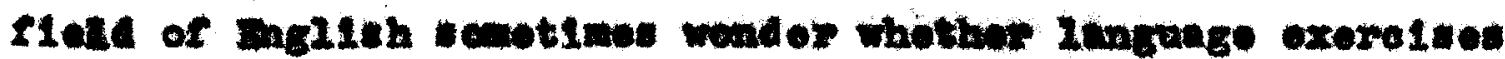

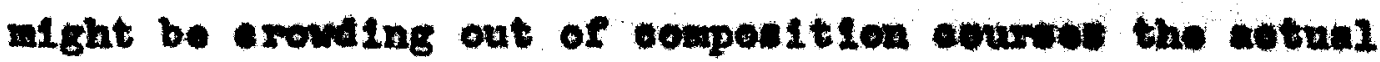

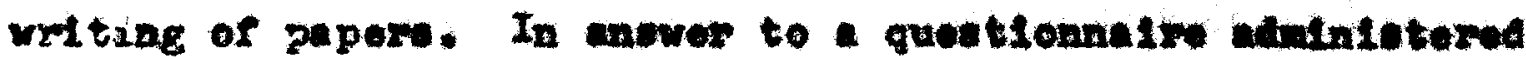
In Yay. 1953, 255 o0110ge frombmen and 25 touchore of high-

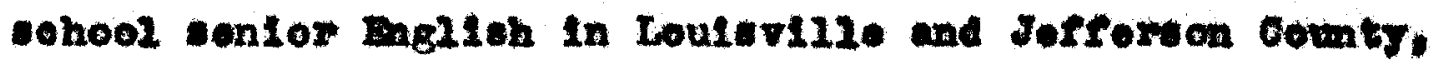
Kontroks, indieated how wueh writing of any kind was cone

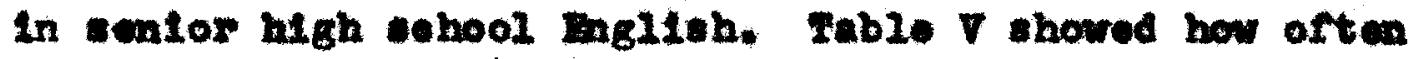

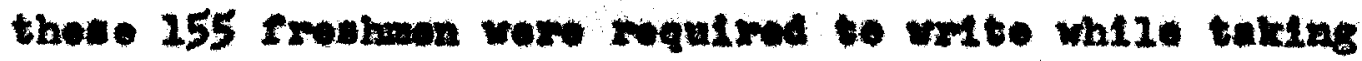
Mighweohool sonior Inglieh.

\section{WALs 7}

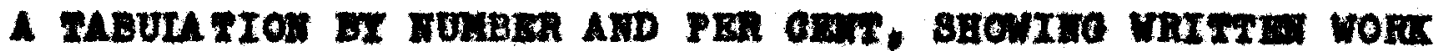

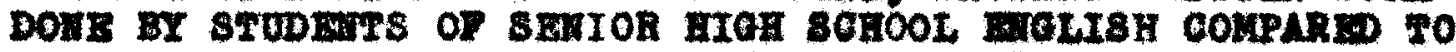

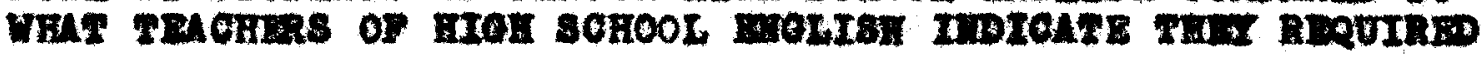

How orten written

Work Done

Almost delly

2-3 times anch reok

About cace waeh weok 10

Docesionaly

Almoat never

Fone
Baglish redohare

Ho. per oent

7

6

2

2

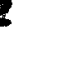

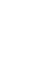


Thirteen, or B.4 per cont, of the tudente were required to write somothing almost daliy, as indieated in rable v. Thixty-1ght, or 24.5 por eent, wore required to wM te from two to three times onoh veok. Forty-five, or 29 per cent, Indieated that thoy had to wito about onoe each weok; whilo another forty-f1te, os 29 por obat, alwost never had to urito. one, of 6 per ount, indieated that ho or whe was required to write erery two or three neokst one, or .6 per oent. Indioated that ho or ohe had to write orery two wooks. One, or .6 per cent, indice ted that no writing at all war roguirod.

students rore divided in their oplation conoerning how woh writing was done in high-achool wentor lngliwh. Porty-11ve students rrote onoe oneh weok. The same number wrote only ocensionally. Fine etudents, of 5.8 per cent indioated almost nover. Acoording to indleatione of the students, the conolusion wight be resched thet some note often, sowe ocoallonu21y, sowe not at all. There we no general agrewent conceraing when otudente wrote is $\mathrm{kgh}$ wohool antor Engliah.

or the group of tenobor in Lontevilie and Jefrerson

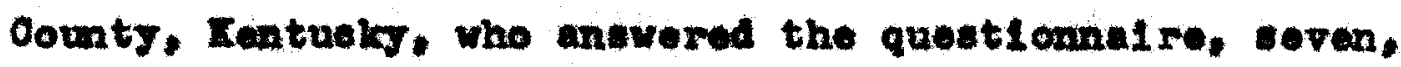
or 28 por oent indloated that written work was requirod almost dally alx, or 24 per cont, indicated two to three tImes each weik, ten, or 40 per cont, Indioated about onoe each weok; and two, or 8 per oent indicated oconsieadis. 
Touchere Indicated more writing of some sort done in high-school wonlor Maglish than did atudents. Minoty-two por oent of the tenchore stated that writing was requirod

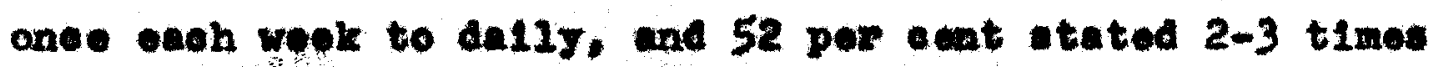
ouch weok to dally. Oaly 2 teuahers, or 8 per oent. adnitted that writing wo done only oeselianuly. Mo towoher Indioated that writing was done almoet nover or that no writing was done.

When the responses of the atudents wore compared to the meapones of the teachers, the teachers indloated that more written work was ase I gned then did the students. Iinety-two per oent of the teachers ald that written woxk

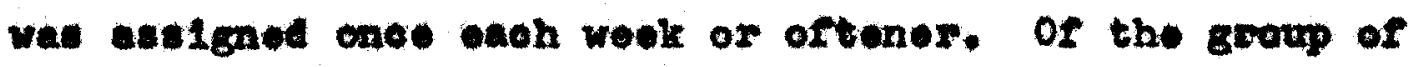
-tudente 35.4 per cont cald oocasionally or leve. Onis 8

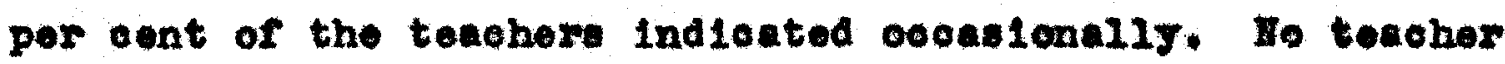
eald elwont nover but nine, or 5.8 per oent of the trients Indloated almont never. The conolusion might be reached, therofore, from information in rable v that the mejority of studenta and teachers Indieate the axporienoe of written work ones each weok or wore. Howner, wore atudente than teachers indleated ocoasionalis and 2wa. .

Thomes, as distinguishod frow written woxk of genowal kind, are briof diesertatlon, a a oholastio

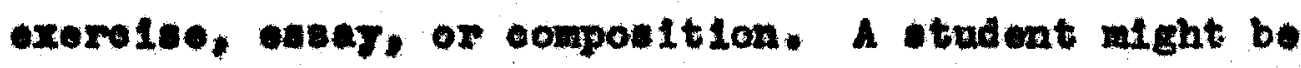

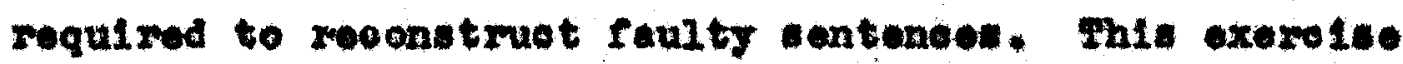


would be writton work, but it would not bo called then. rable VI show hou ofton those 255 college freshmen wroto thower wh120 taking high-eaboel sentos English.

\section{TABLE VI}

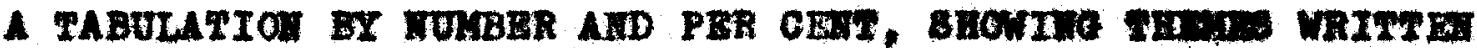
BY STUDEATS OF HIOH-SOHOOL SEIOR HETISR COMPALO TO THEMES

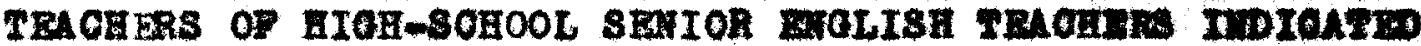
THET RBQUTHED

How Orten Themes

Wor Writton

Almoat dally

2-3 times each weok

sbout onee ach wook

Decasionalis

Almost nover

Yone
Bagliah Teachore

Ho. por cent

0

2

16

4

2
Dollege Drouluna

Ho. per oent

1

.6

$6 \quad 3.9$

$42 \quad 26.5$

77. 49.7

$20 \quad 12.9$

$5 \quad 3.2$

Tab20 vI wowe that on $2 y$ one, of .6 per eent, of the atudents sald that he or the wrote thome almost delly. s1x, or 3.9 per cent. sall they wrote themos two to three t1mes exoh wook. Forty-one, or 26.5 por cont ind teated that thoy wrote themes about onoe each wook. serenty-seven tated thoy wrote thomes coly oscalionelly. Iwenty. 0. 12.9 por oont indicated that they almont never wrote theres. Hve, or, 3.2 per cont sald they wrote none at all. The mojortty of the students indioated writing thowes about onse can 
woek, or oceaslone1ly. Only 20.6 per cont ohooked other anwwers. Agaln, a in the writing of any cort, wtudenta showed no general agreoment ooneerning when they wrote themes in hlghmechool entor nglieh.

ovor oxo-half, 16, or 64 por oent, of the teecherw indiented hering requized writtion thomen about onece each wooks only 26.5 por oont of the atudents indioated having written themes once oach weok. The largent group of studente, 49.7 per oont, anawered oceastonellys wherese, only 26 por oent of the toncher gave this answor. Information in this table acoun to indieated thet the me jortty of the tenekiom way the studexts wrote thomos onee weh wook or more oftmi whereas, the ma fority of etrudents exy only oweanlonelly or 10se. Perhap teachore remomb or wore distenotly, as ther toech the matoriel more then conce.

Whother the etudent writes a good or a poor paper 18 mony t1mo o cotermetned by the sub feet he ohooses or 1s asalgnod. Ideas whloh the student oenuld ors romote and unveluted to himolf rarely provide the fabsie for a encoeserfil thame. On the othor hand, if atudente writo about sub joot: that 1ntereat them, they are moro 11kely to commingate to the reader thats thoughte and foelings. Fab10 VII Indiontes the soure of the sub foottl for themes written in highotohool senlor English. 
XATS VII

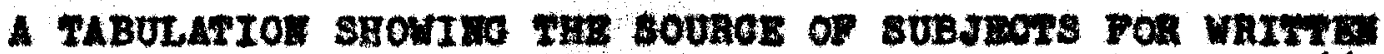

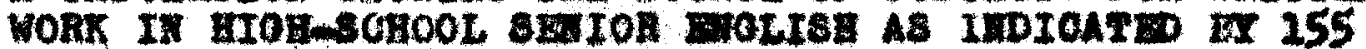

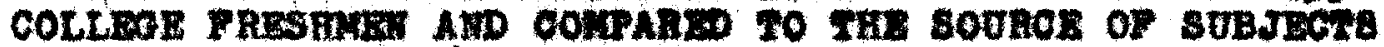

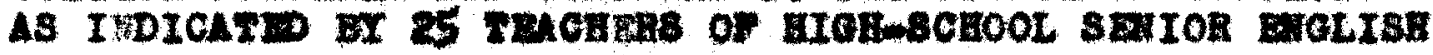

Sub joete Taken From

Liets found in text books

Pertemel experience

reccher ouggeet Lone
Inglith Toaher:

Ee. pow ent
Col2oge Preshenen

No. per eant

Thirtyulne, or 25.2 per ont, of the studente state that they found abj jeete for thesf thase from ilats in the text book, seventy-ight, or 50.3 pas oent, etate that

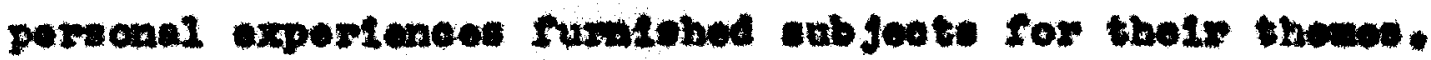

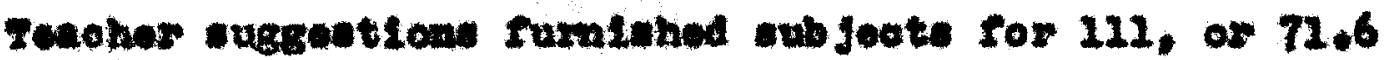
per cent. Wany of the etudents ohooked mors then one soume of mubjeate for themes, bonoe the totel number of woplie total now then 255.

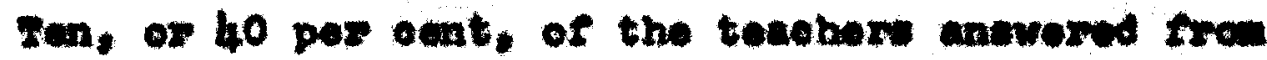
Ilete found in text books twenty-two, or 89 per cent,

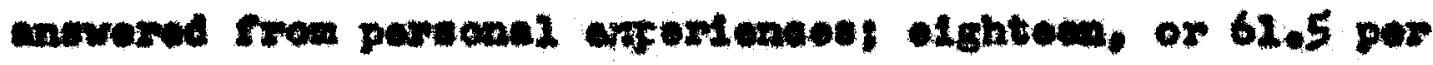
cont, anowored fram toeshor aggenstlons.

Now of the etudeats indianted that they wrote srem

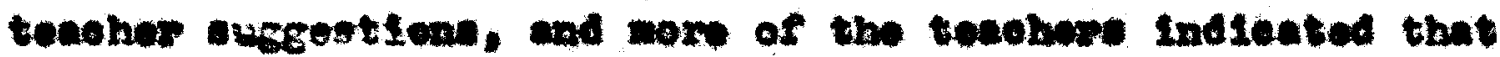

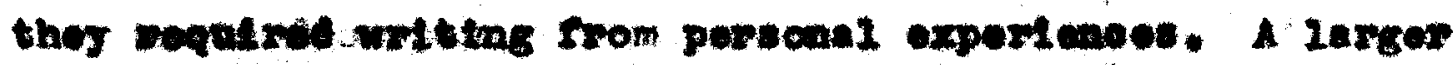

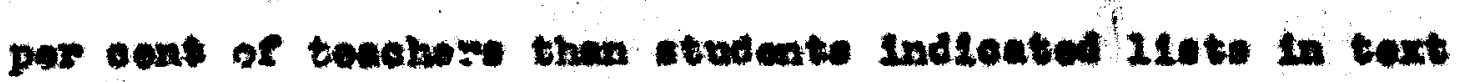


books as sourco of abj jeets for themes. Teachor auggeations scem to be of moxe importanes than the teachers themelved realiso; porhaps the atwate try to ploese the toedher or write for the tewhor,

In high-wehool aenlor mglith wany trpos of writing are cone. rable VIII showed the types dene by the 155 colloge freshmen aurvejed at the oniversitj of Lonierille.

\section{RABLE VIII}

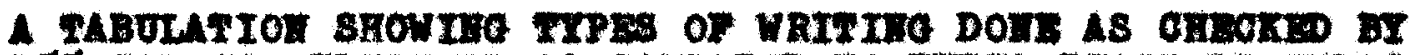

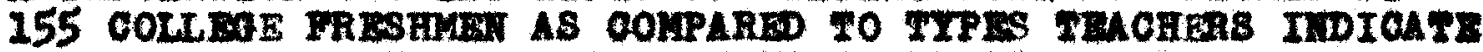

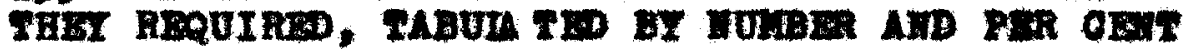

sypoe of vriting

Blography

Autoblogxaphy

Derintition

Oomparison

Book Reviows

Analyals

Sumpary of Proelt

Deseriptive

Charates inalyelo

Pertunasion

Oritieal Analyois

Tern Papero

Philesophioal

Diseviselea

Personal Bxpertmes

Outilnes

Ixplanation of a mgliah renehore

to. por ant

$\begin{array}{rrrr}8 & 32 & 60 & 38.7 \\ 12 & 48 & 58 & 37.4 \\ 6 & 24 & 32 & 20.6 \\ 7 & 28 & 34 & 21.9 \\ 23 & 92 & 121 & 76.1 \\ 7 & 28 & 32 & 20.6 \\ 17 & 68 & 39 & 25.2 \\ 15 & 60 & 54 & 34.8 \\ 15 & 60 & 36 & 23.2 \\ 2 & 8 & 7 & 4.5 \\ 8 & 32 & 19 & 12.3 \\ 13 & 52 & 66 & 42.6\end{array}$

2

21

29
College Freahmon

No. pow oent

$60 \quad 38.7$

$58 \quad 37.4$

12176.1

54,8

$36 \quad 23.2$

4.5

12.3

42.6

85.2

9562.3

$59 \quad 36.2$ 
Dovoribing the typos of writing thoy did a calow In high sehool, 38.7 per cent of the students indicated thoy wrote blography as cempared to 32 per cont of the teacher who required blographies. silght2y mow then 37 per oent of the studente atated thoy urote on untoblegraphy as compered to 48 por cent of the teachow who required atoblographies. Almot 21 per ont of the atudente sald

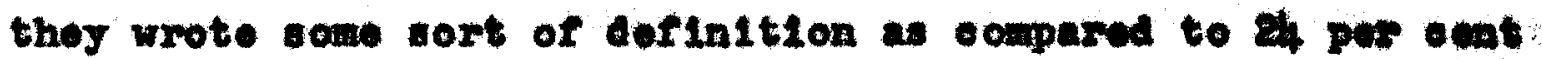
whe roquixed derinitions. Alwowt 22 por oent of the ctudeate

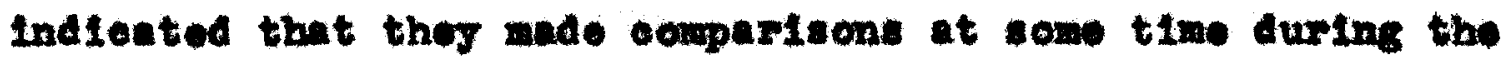
enlor year of high sohool al compared to 28 por oent of the teachere who required ocmperiteone.

The highest nwiber. 78.1 per oent of the vtudents sald thoy wade written book reviown, as compared to 92 pow ont of the teleker: who required written book reviewe. Almoat 21 per cont of the atrdenta indlosted that thes ade analysed, as oorparve to 28 por cent of the teachere tho required analjees. About 25 per oont of the students Indiested that they wrote a swarany of prools, al compared to 68 por cont of the toashore who requixe a townery or preole. Rerbups the otuderate wrote a presis but did not remember 1 t by that name.

Dosoriptire writing was ohooked by 4.8 por oent of the otudeats as oouparve to 60 por oent of the touchores ohareoter encigues was ohoekch by 23.2 pos oont of the 
studente as compared to 60 per cent of tho teachows. OnIy 4.5 pox cont of the atudente sald they wrote come pewwan

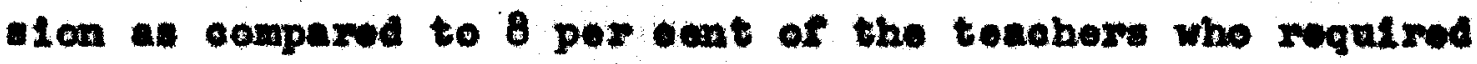
poseuasion. Onls 22.3 per ecint of the etudente wrote a critioel andrais, at compared to 32 por oent of the teachor who required a extecel analyais.

4 high peroentage, 42.6 per cent indiested baving to writo term papar al oomparod to 52 por ont of the touhore whe roquired a torm paper. or the students, 5.2 per ecat wrote sone philovophion disouseton, as exmpared to 6 por cont of the teachers who required phllosophioal diaweion.

The largeat number of $012,61.3$ per eent wrote trom perecall experience, at comparad to 84 per oont of the tenoher indieating they required writing from peronal experionoes. About $36 \mathrm{per}$ cont of the atudente made outilned. ac ocupared to 76 por ont of the tenchers indieating that they required outilnes. About 16 por oont of the students Indleated they wade an explanation of a proeese, al ompared to 36 per eent of the touohore who required the wame.

Oa the whole the teabher ohedked arger verioty of rogulred writinga. The pereentegen wore highor for the teachers on 211 exeopt blography and phi20sophteal disousaton. Perhape comprohoneten of the moanting of 1 tom 11ated wa alfrioult for the studmte.

Proparation for the actual writing of a paper is of the utmost importhnos in effootive mitten ocmunication. 
Teachere of raglish agroe that indloatione of planning and organialng materials are desirable qualltien in tudenta. Tablo IX ahowed the proparation for writing of thomes as Indionted by 155 colloge rromben at the University of

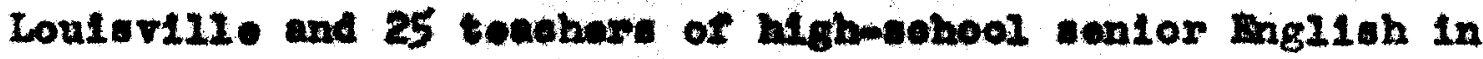
Loutarille and Jeffowen County, Kentwolsy.

\section{TABLE IX}

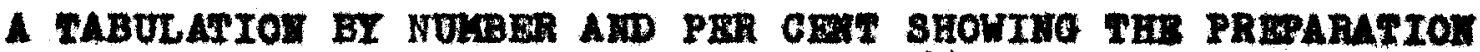

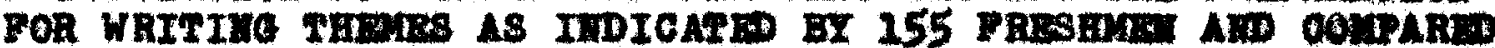

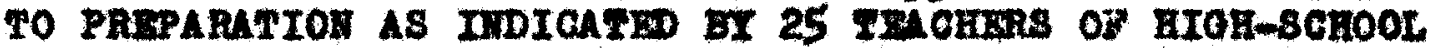

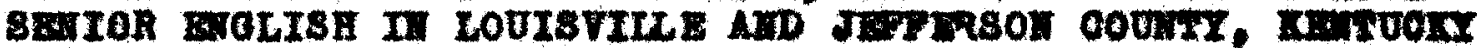

Preperation

Writing Ontilnes

Preparation of a thodel:

Leplanation of a Typo of Nriting so be dene

Io Proparation
Baglide Teabore

Bo. pow cent

16

10

17

0
64

40

68

76

25
College Preahmen

No. per cont

$50 \quad 32.3$

2314.8

49.0

9.7

In desertbing the trpe of preparation they had for the attual writing of thames, flfty, of 32.3 per oent of the atudento indieated that thoy made an outilne. pwontythree, or 4.6 por cent, Indleated that they had atudiod a model papofi while 76, or 49.0 por ent indieated thet thoy had eare types of vrlting explained to them. Anothor 15. or 9.7 por cent, wrote in the work, newe," os "no preparation." Wost of the studinte Indeated proparation 
of sowe kind, howorer, 9.7 per cont stated that they hed no proparation. This probubly aceounte for some of the poor writling that teabore oemplete abeat.

Ooneerning proparation, elxtocan, or 64.0 por oont of the toachore of bigh-sehool sonior meilith in Louleville and Jefferson County, Kontuoks, Indto at od that they requilred outlines; ton, or 40 per eont, linted proparine a 'modell! seventeen, or 60.0 per cent indionted the oxplanation of a type of writing to be done. Hone anid "no properation." When the responsen of the atudente wore compared to the sooponues of the towehere, the poreentage indleating proparation for writing was higher asong the teachese than the students. Fifteen, or 9.7 por cent, of the students Indieated no proparation whatever; no teachor man that indication.

Grammarlane are not agreod on which type of grading or revising of themen wa proved most effeetive in the toeohing of malish. Some of tho teachore insiat that oorroctions should be written in; othore say exrore should bo pointed out and cozreotions made by the studente. The number and per cont of the roplles made by the 155 oolloge freahmon and of the repllex mate by the 25 teachore of highmeohool wonlor anglieh rogarding the nowner in whloh grading wes done is show in rable $x$. 


\section{TALE $\mathbf{X}$}

4 TABULATIOH BY TUBBER ADP PER OET BHOWIHO THE MTEODS OP

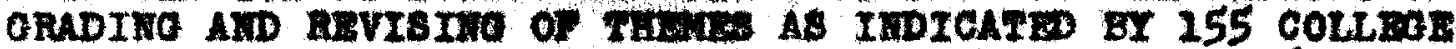

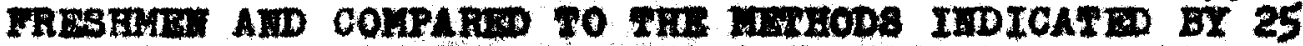

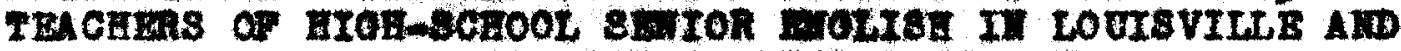

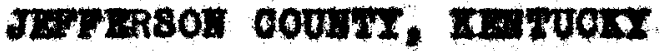

Mothods of arading Daglish reachore Gollege Frowben and Revialns

No, por oont 10. par oent

Noooraling to some

'Rating of Irwerlon

orading syetom

11

44

80

52.6

By Vmiting in Dorrections 18

72

102

65.8

By Supplying the Proper Punctuation

$17 \quad 68$

78

50.3

By Indleeting pleces whore

Paragraphe thould boginl7

68

$66 \quad 42.6$

By Indieating Proper

Bentenoe st muoture

17

68

$61 \quad 39.4$

By Ind loating Proper

Dlotion

25

60

30

24.5

Emoza Marted

1

.6

Dan't Know

$2 \quad 2.3$

Elghty. of 51.6 per oont of the reaponnes ohouked that papere werv graded by some cowt of a 'rating' or nuwerelal groding gyatem. Ono-hundred two, or 65.8 per ent of the atudenta indieated that tenohor: wrote in the ocrrection. 8oventy-elght, of 50.3 per cont, and the proper punetultion was oupplied by the teacher. B1xty-tix, of 42.6 par

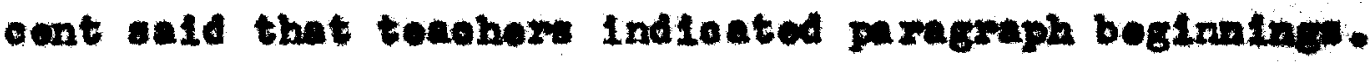


81xty-one, of 39.4 per cents ald that the proper sentenee atruoture was indicated by the telaher. Thirty-olght, or 24.5 per oent, of the etudente wald that proper diotion was Ind1eated. Only one etudent. or .6 por oent, andwered by writing in the expression. "errore marked". Two of tho group, or 2.3 per cent urote in "con't mon". since the studenta chooked more than ono mothod of grating, tho totel number of replies val wore than 155.

Varlous waye of chooking and rovising thomes vere used in the teaching of high-wohool sentor Anglish as indicetiod by 155 freshmon surveged at the oniveralty of Loulswile. Hang of them ohooked more than one mothod of correcting thomes. Only one tudent indicated that orrore woro maxkd. Two otudente, or 1.3 per cent indloated "Don't xnow as the enwer. Frow indigatione of the etudente no eortain wey of cheoking or revieing themee was uase.

Or the group of 25 teachere of high-pohoel sentor Fnglish in Loulari2l and Jerfereon County who anawered the questlonnalre, eleron, of 44 per oent, eteted that the graded acoording to som 'rating' or numorical grading

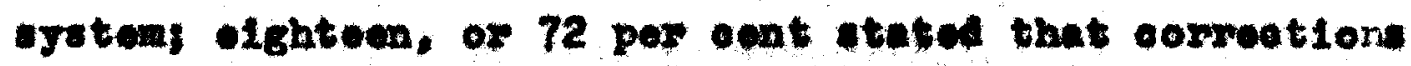
were witten ins seventem, or 68 por ecat, stated that they eupplied proper punctuation; seventepa, of 68 por

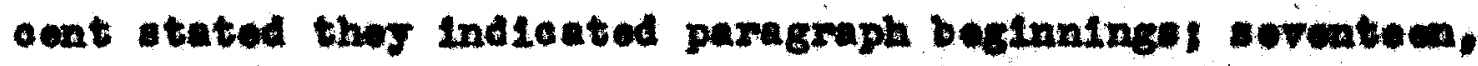


02 68 per oont stated that thoy indicated proper sontenos atruetures fiftew, or 60 por oent sald they Indiated proper dietion.

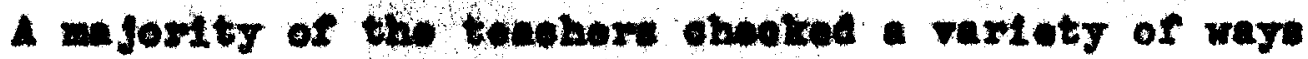
of grading and rovialng of themes. Oaly cas, Moeording to cone sort of 'rating' or numonlonl grading arotem, was ohooked by leas than 60 por cont of the toaohore. Thle wothod of greding and revialng thomes roocl rod the vote of 44 per oent of the teachers.

When comparing the responses of the teachers to the responses of the students, agein the teachore Indicated a greater pereentage of Iteme eorreeted then did the studenta. studente have a highor perecntage in ane intenoe, the 'rating' or numarioal grading aystem, whore atudente bad 51.6 per oent to 44 por cont for the teabhers. On Indieat1ng proper dietion, 60 per oont of the teanhore ohooked "yes" while only 24.5 per cent of the students oheoked "yes." Probably acme of the atudente did not know funt what was

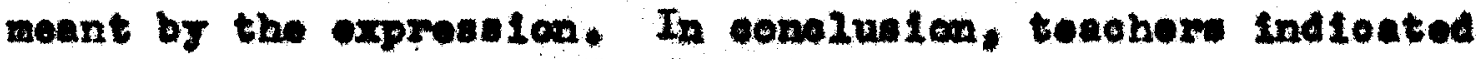
that more dotalled grading of themen was done then the otudenta eatimated in their replies to tho eame inguiry. An erfort was made to doternine whother tenohera in high-sohool senlor Inglish gave letter gradev for the term.

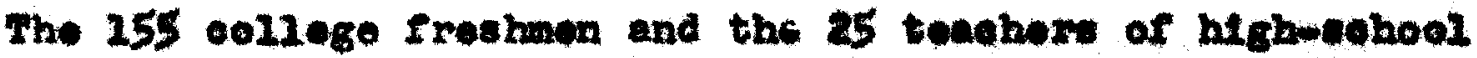

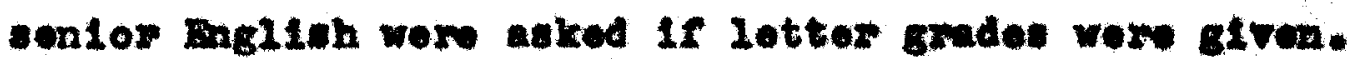
2able XI howred the reulte of that inquixy. 


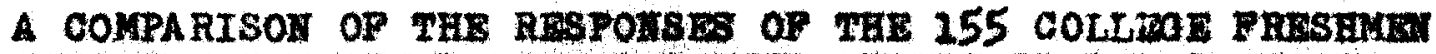

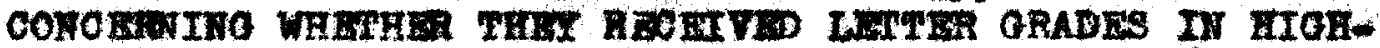

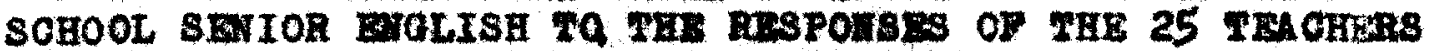

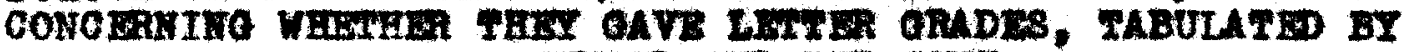
IUTBE AID PIn CART

Recelved

Lotter arados

Yos

No

no answer
Tnglish Teachers College Froghwen Ho. per ceat Ho, per cent 2184 $3 \quad 12$ 28
$115 \cdot 74.2$

$28 \quad 18.1$

$12 \quad 7.7$

rable XI showed that when anked whothor or not they rooelred letter grades $(A, B, C, D, F$, Bto.), 215, or 74.2 per cont, entwered "Jea", while 28, or 28.1 per oent eneriered no." twrelve, or 7.7 per eent, mede no roply. Thus the jority of the atudents ald thoy roodrod letter grader.

monty-ons or 84 por cent of the twenty-51ve teachere of high-achool senlor Pagliab aurveyed indicated that they gav letter grades. Only three, or 12 por ent, of the teabhore ald thor did not gire 2ottor gredes. Two, or 8 por ecat ald not warer this question. The total number of anmwers ald not agree with the total number questioned as meny timea both answers wer. Indieated. Perbaps on aome papera they reetved lotter gredes and othere numerleal. 
From the date In Table XI, the oonelualon oan be

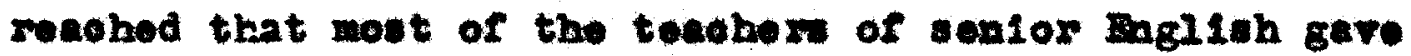
lotter grades. About 6 por eent of the teachers and studonte gere no anwer as to whothor they rocelved or roquired zetter gredes.

arenter learaing opportunitios are likely to reevit frem the oarly returaing of papera. If a atudent has not $100 \mathrm{t}$ he enthuliean for the paper by the tife it it rotured. ho Is more likely to learn from correations: of his erroxt, One hundred fifty-five college freshmen and 25 tenehers of

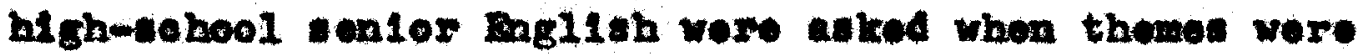
roturned. Theis anwere were ahown in tebie XII.

\section{TABLE XII}

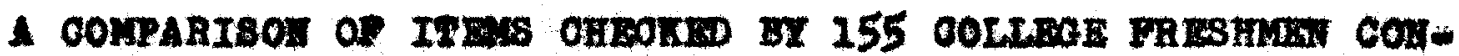

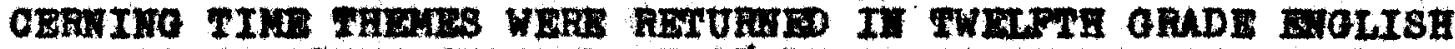

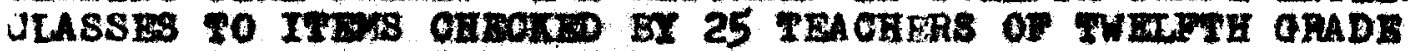

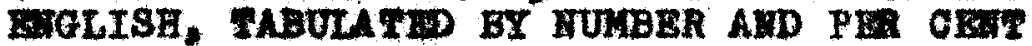

Thomes Returned

$$
\text { Paglish Teeohere }
$$

No. pere cont
Colloge Freshman Io. por oent
The day after they were vritten

The weok efter they woxe witten

Mot returnod at all othere
936

15

60

0

2

8
$24 \quad 15.5$

$108 \quad 69.7$

149.0

42.6 
In reaponse to the queations portaining to the time thenes were returned, 24 etudente, or 15.5 per oent listed tho dey after ther wore witten, as indio at in Tablo XII. One hundrod elght, or 69.7 par cont, indiokted the woek after they were writtea; fourteen, or 9.0 por eent ald they wero not returned at all. The majoxity of atudents Indicated themes viere rotumed the following wolk bowever. 25.5 por oont Indioated the day rollowing: 9 por cent, not at all.

Nine, or 36 per cent of the teechers answering the questionnalre tated that thomes were retumed the dey after they wore written. Pifteen, of 60 per eant, etated that they were returned the week after thoy were written. Wo toachar Indicated that thomes were not roturned at alI; howerer, two, or 8 per oent, gave other anewere.

When the responses of the atudents wore compared to the rosponsea of the teachers, more teachers than etriognts Indioated that pupers were roturned early. Pourteen, or 9.0 per cent of the atudents atated that themes ware not returned at all. The pereentage of teachere saytug themos wore returned the day following uas 36 per oent, nore then tw100 os great as that of tudents indiesting they wor returnod the day following. Therefore, rab2e XII aeoms to indicate that teachers say papere were returned sooner than to the students. 
Learning oxporionoes from potuxnod written wowk can be many when errore are pointed ont. Manj toaoberm aLmply point out erfore and sugseat eorrotions. Others leave the disouselon Iergely to tho otodeatef hile many take adrantage of the audiompleunl alds. Fable XIII abowed what 155 .00110ge freshon at the Malverulty of Loulevillo end 25 tenohore of

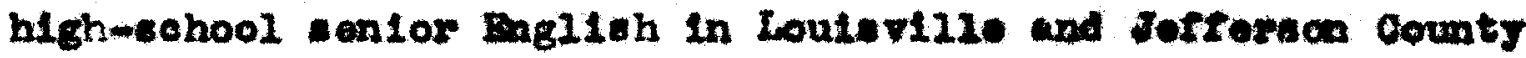
Indloated In senlor singlish,

\section{TABLE XIII}

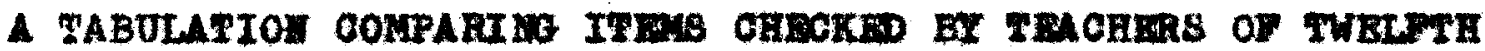

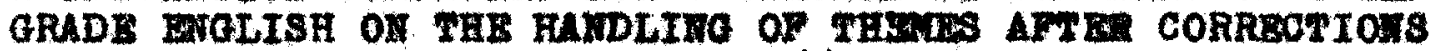

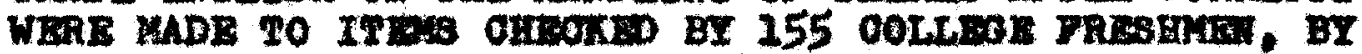
HOUBER AND PER CEMT

How Handzed

$$
\text { Inglioh Teacher: }
$$$$
\text { No. por cont }
$$

$$
2
$$

8

1244

72

18

Rommentten

Nothing done

General oprore poldtea out by the towohor

Aud10-risuel alds

$28-72$

8

0011ege Freahmon

Ho. per oont

34

22.9

rable XIII Indleated that 34 , of 21.9 per oent of the

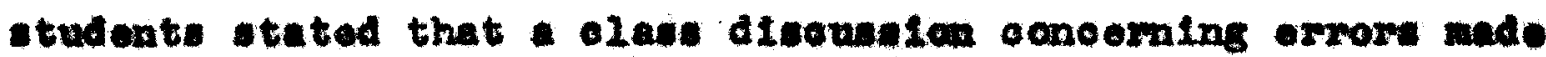
followed the corrootion and retian of papere. of the gromp. 111. or 72.6 por cent, sald that the generwal emors wore 
pointed out by the teauher. One, or of por ent, indleated that the papers were re-uritten, slx, or 3.9 per eent, sale that nothing wal dene. In othor worde, 93.5 por cont of tho atudents indionted that thowe was elase disousefon or that the teacher pointed out the orrorn.

of the group of 25 teachere of hlghinohool confor

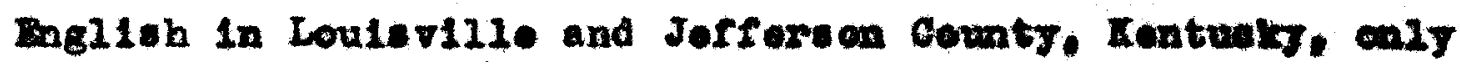
two, of 8 per cent, stated that themes wore returned and disoussed in clase; eloven, or 44 per aent, indieated that the generel exrors were polnted out; eighteen, or 72 per cont, Indieated that andio-rinual alds wore ueed. This last point seained surprising sinee onls one atudent indieated the holp of avdio-viounl alde. Wo teroher indicuted that themes wore rewrittion or that nothing was done. Whon oomparing the responses of the teachers to those of the students, the mority of students, 71.6 per oent, stated that the exrore were polnted out by the teacher; whlle only 44 per cont of the teachers gave this roply. About the

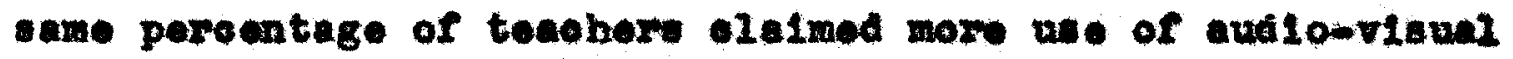
alde; whoreas only one, or .6 per cent, of the student: ohocked audiompleusi alds. Porhapa tonohore in Loulsvilie and Jefforwon County had mocese to more of these alde then everage.

students who have corrected errors made in the writes of themen aro mone ilkely to remember and profit by thels mistakes than if no corroctione had been required. Tablo XIV 
showed the manner in which tudents waxe required to revise thomes retumed to them as indieated by the 255 oollege frodhen obeoking the questionnalre and conpared to revisione whioh teechere Indicated they roquired.

\section{TAELE XIV}

A TABUIATIOT SHOWTHE HOW PAPERS WERE REVISEO AS IDDICATEP

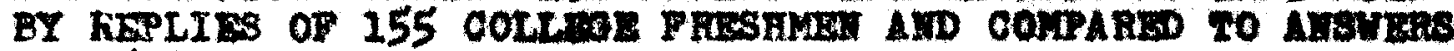
OF" 25 TBACHERS OF TICH-8CHOOL SETIOR MTOLISH, BY HOMBER AND PER CBET

Eow Revised

English Trachers

No. por cent
College Freshmen

Fo. per cent

Students write in

the corrections

520

50

32.3

Theme paper

ro-rixt ton by the

student

16

64

37

23.9

Did tho tudent make

marginal correotion 7

28

$24 \quad 2.5 .5$

Xone

$38 \quad 24.5$

othere

$4 \quad 2.6$

Pifty, or 32.3 per oont of the studenta indloated that they wroto in the oorrections while 37 , or 23.9 per cent ald the papers wore romritten. Twenty-rour, or 15.5 per cont of the atudente wald thay made marginal oorreotion. Thinty-olght, or 24.5 per oent, indieated that they made no oorrection. at all, This ecoms a large 
number to heve nade no corroction, The in rgest por cont of the students indicated that they wrote in the oorroctionas whereas the next lezgest por cont indicated that they made no oorrectione.

From the group of 25 tecohore of highidehool sonior Ingliah in Loulavillo and Jorforecn dounty, Ifre, or 20 per cont of the teachors stated that utudente wrote in the

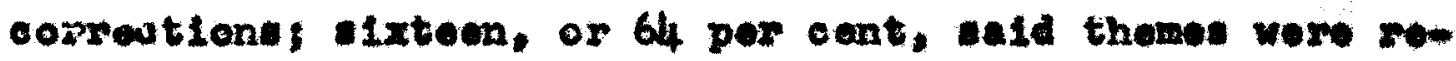
written; seven, or 28 per cent sald studonts made marginal corrections. Hot one of the teachers Indianted no correotione. Tho largest number of toacher. sald that themes wore rowritten; the next lergest number sald that atudents made marginal correstions.

When comparing the responses of the 25 teaohers to the reaponses of the 155 college freamon, Tad Io IIV Indloated that teachors olnim more corrootions than do the students. Righty-fenr per oent of the teachere sald that corrections were writton in or that the student remrote the paper: whoreas, only 56.2 por coat of the etudeate gave that andwer. Inirty-e1ght, or 24.5 per cent of the otudente ald that no revision wae required. Hore teachore than atudonts olainod papers vore romritten. Thirtj-olght, or 24.5 per cont of the students sald that no rovision was required; no teacher clalmed this. 
The pratice of oorreoting themes and making then accessible to the students has proved advantegeous. studenta prorit by part mistake and at the same time note their Improvements in writing. rablo XV showed what beoamo of papers after corrections had been made an Indiected by the responsed of 155 college froshmon at the bulveralty of Loulovilie and 25 teachers of high-gohool anlor Dgileh in Loulav121. and Jofferson County, Kentuoky.

\section{TABLE XV}

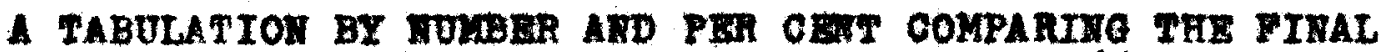
DISPOSITION OP THEABS AS INDICATBD BY THE 155 OOLLEAE

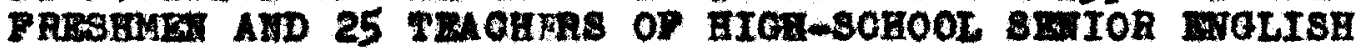

That bocame of thomes Inglish Toucher College Freshmen No. per cent Ho. per cent

Became a part of the student's soin. rocord

9

7

9

5

Destroyed by the teachor Don't know

in the olasenoon

Destroyed by the atudent
36

$21 \quad 13.5$

28

$22 \quad 14.2$

36

20
$74 \quad 47.7$

3321.3

$7 \quad 4.5$

Conoerning the final claposition of themes, twentj-one or $13.5 \mathrm{por}$ ont, of the students anawored that thes thenes beane at of the student's record. Twenty-two, or 74.2 por ent answered that they wer put 'on $111 e^{\prime}$ in the olanto room. The langeat number, ceronty-four, ox 47.7 per oont, 
answered that they were destroyed by the otudent. Thirtythree, or 21.4 per cont anowered that they rere deatroyed by the teacher. seven, or 4.5 par cent wrote in the vords, "don't know."

8Inee otudents wore unged to ohock more than one answer when necescery, the number of enmere totals wore than the 155. The largeat poreentage indicated that the papers were destroyed by the otudent; the next largest poroentage whioh is less then half the flrut one mentloned indicated that themes wore deatrojed by the teacher. More student: than teachore steted that pere were destroyod by the tudent.

From the group of 25 teachers of high-sohool senlor English who wexe aurveyed in Loulevilie and Jefferson County. nine, or 36 por cont, of the teachers sald thomes bocame part of the student's record; seven, or 28 per cont sald they were put 'on r116' in the elaseroom; nine, or 36 per cent ald they were destroyed by the otudent; and rive, or 20 per cent sald the papers were destroyod by the toacher. Teachers waro divided in their opinion as to what boosme of theoses after corrections had boen made; thirty1x per cent of the teachers aleimed that thomes bocame a part of the student's school reeord. The and number Indieated they were destroyed by the atudent. However. more teachar than studonts elained that thomes beeane a 
part of the atudent's sohool reoord.

When oomparing the reapenes of the 155 oollege froshmen to those of the 25 tencher of high-sohool senlor ming11sh, 64 por oont of the teachere seld that the thonos became a part of the student's sohool reoord of that they were pat on 2110 in the olasuroom whoweas, only 27.7 por ont of the students gave thet answer. Is many as 73.5 per cent of the students indionted that the pepere wero equtroyod or gave "den't know" as the answer. A larger peroontage of teachers then students ind foated that papers beoame a part of the atudent' nchool record; whereas, a larger peroentage of the studente than the teachor indieated themes were deatreyed by the etudent. 


\section{CHAPTER VI}

Othor Toples Related to the roaching of Bngliah 
CHAPTER VI

OTHER TOPICS AELATE TO THE THACHIHO OF EOLISH

Pormal lossons in epeliting are not offered in hlgh school as in grede wohool, but they are Included as part of the Bngliab courwe In many Instandes. The 155 o0lloge Freakmen eurvejed at the Onirorsity of Loularille and the 25 teachers of hlgh-wohool cenlor Ingliah were ackod if formal lo soons in epelling wero taught in the enlor jear of high sohool. If wo, was it written or oral. rable XVI hows the reaults of this inguiry.

\section{TABLI XVI}

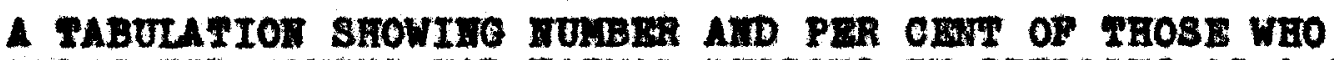
IHDICATED HAVIIO HAD FORML LESSOHS II SPELLIMO AS A SEMIOR II HIOH-SCHOOL EOLISH AS COMPIRTO TO TRACH BRS OF HIOHSCHOOL ETOLISH WHO IIDIOATED HAVIMO TAUOHL PORMAL LEBSOHB II SPELIIW, AWD WHEXHER THAT SPBLLING WAS WRITTEN OR ORAL

Spelling

Engliah Teacher: Colloge Freshmon

Ho. por cent Ho. por oent

Formal Lessona $\left\{\begin{array}{lrlll}\text { Tos } & 29 & 76 & 95 & 61.3 \\ \text { 10 } & 5 & 20 & 47 & 30.3\end{array}\right.$

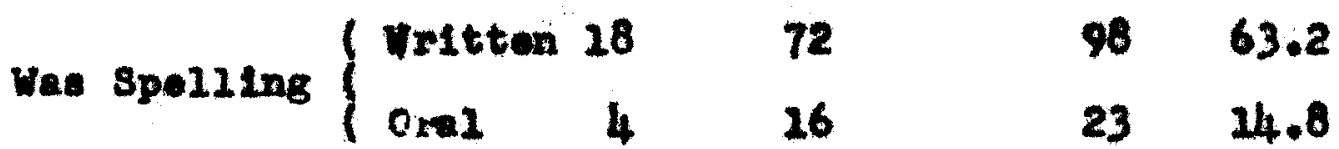

Inoty-rive, or 61.3 per eant, anwered that theg had formel 10 asone in opelling as wators in high-wohool Figlioh. S11ghtly moder haif the number who indic ted the 
had formal lessons in spelling 47, or 30,3 por oent, indleated that thoy had no romal lossoas in apoling. Whon asked whother the apelilins was written or oral, ninety-olght, or 63.2 por oent of the total grow atated that they had written opelling leawones wh1le twenty-three, of 4,0 per cent, eald they had oral spolling lessons. Sow of the otudeate probably had apolling; but they did not oall it formal lessone in opeling, sinee the number sugling thoy bed written lessons in apelling is greater then the number eayIng they had formal lestons in epelling.

The conolueion oan be reachod that more of the etudents had formal lessons in apeliling. Those who did not, had Informal lessons in pelling. Of those who olalmed to have had opolling, the mafority had writton opoliling in proference to oral.

IIneteon, or 76 per eont, of the teachere Indioated heving taught formal is seso in opelling: five, or 20 per ont, sald they dis not. Bghteen, or 72 pos cent indionted having had written opollings four, or 16 por oent, indicated haring had oral spolling 1 larger peroentage of teachere

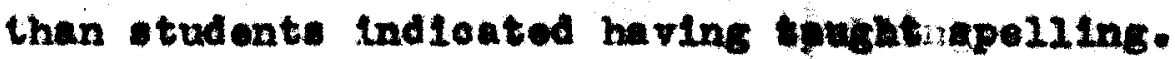

Hodt of the teachore Indioated having conduoted formal olaseer in speliting. One tencher ald not answer. Host teacher stated that the spelilng was witten rathor then oxh1. 
In this seation an attempt was wade to rind out where upelling words wore teken from. Have tho students studied thetf own errowe of eterybedy' exworm one hundred fifty-

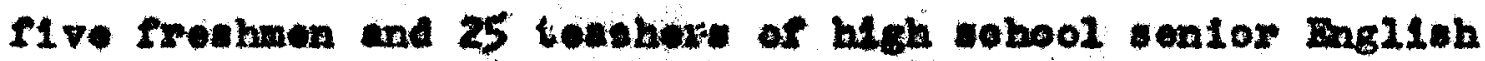
In Loulerille and Jefforwon County, Imatuoky, wore alked to Indieate where they got the worde for thelr epeling. Table XVII showe the results.

\section{TABLS XVII}

A TABULATION COMPARINO THE SOURCE OF SPELLIBO NORDS As

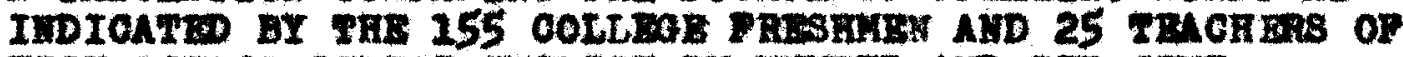
HICE-SOHOOL SEIOR BUOLISH BY MUNBER AMD PIR CEMT

Spaling Worde raken from

Liate in texts

Liste oute1de toxt

mroom in Written Vork

Liste made by otudent
Bngleh toadher

Ho. per cont

52

32

52

13

23

8
College Frenhmen

Ho. per cont

The majority of the atudents who took apelling in

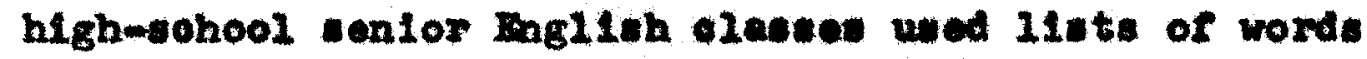
found in texte. Sorenty-rive, or 48.4 por cent of the fresheon Indionted this souroe. Iminty, or 29.4 por ount, of the students Indionted that they uow woxds found outelese the text. Iwenty-f1re, or 26.1 per cent indieated that thoy 
studied words taken from tholr writton work, only three, or 2.9 per cent, Indieated that thoy studied words celeoted by the student.

Almost hif the students indiested haring tekon words from liate found in texte. A mali poreentage indicatod 11ats cutalde the toxt and orrors from writton work as the souroe of apeling words. Three studente, or 1.9 per cent. Ind loated that they otudied lists made by thomolves. Thirteen of the teachers, or 52 per oont, Indleated taking epelling words from lists in textef elght, or 32 por oent, Indiceted 1ista outside the text bookt thinteon, or 52 per cent, of the teachere ilut exrors in written work as the soure of epelling words.

Pifty-two por cent of the toechem indieated that opelilng worde woro taken rrom 11sts in texte. The same number of teachors indicated that opeling words wore taken from exrors in writton work. A smaller number of the twacher indicated using worda from 110 ts outelde the text. No teeoher indicated that the student made his oun liet. Hety-two per cont of the teachere indloated that they taught words frow orror in uritten work; whoreas, only 16.1 per oent of the students indieated this courec. Teechore know that should bo tabght.

A langer percentage of students Indloated that their worda were taken from libts found in texts; whereas, woot of the teachore indieated 11sts in texte and omore in 
written work, both belng veleeted by 52 por oent of the teachers. A larger pereentage of teachers then studente Indicated that words were takon rrom llote outs1de texts. No tenohor Indloated that opelisng lints were made by the atudent.

Do opelling error affore an opportunity for zearninge When teachere discovored what work studente eould not epell, what did they do to make the teaching altuation roalt the data in Table XVIII showgd what the 155 colloge frosman at the University of Loulerilie and the 25 teachere indioated was done about alespelied worda.

\section{TABLE XVIII}

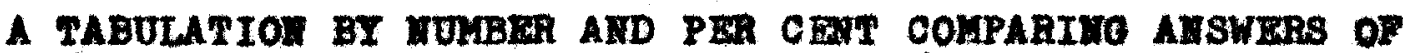

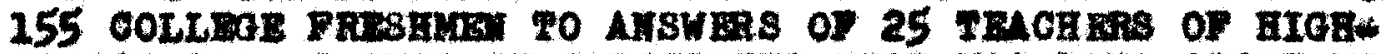
SCHOOL SENICR ENGLISH OOMOERTIMO WHAT WAS DONE ABOUY MIS* SP BLIWD WOPDS.

Hisspelled words

Bnglish reachera

10. par cont

Discanded

Ignored

Ro-writton

Re-teoted

Marticed

Ponnilsed

Disoused

$\begin{array}{ll}2 & 8 \\ 0 & \\ 5 & 20 \\ 1 & 4 \\ 1 & 4\end{array}$

8

20

4

4

4

\section{College Frobluna}

No. por cent

27

27.4

5

3.2

$16 \quad 20.3$

10

6.5

31.9

$2 \quad 1.3$

1.6 
Concexning the worde that had been misapelied, twentysoven, or 17.4 per cent, of the atudents indloated that thes disoarded worde that hed bew miespolled. Fire, or 3.2 per cent, Indloated that the micupelied worde wore ignorod. s1xtoen, or 10.3 por oent, Indieated that thes romrote the words number of times. Ton, or 6.5 pas eont, wald they were ro-tested on the worde. Three, or 1.9 per cent, sald the worde were marked. Two, or 1.3 por cent, indiented that miespollod words were 11 sted and the student penal1zed. One. or .6 por cent, Indleated thet misepeliod words were disoused. Teachere did not indleate having done much about alsspelled words except. to mart, correct, or to disouns them. Only two teachere, 8 per oent, Indieated the words wero writton. Studento did not indleate being ponallsed. sixteen, or 10. 3 per cent, stated words were re-written; and ten, or 6.5 per eent, etated that words were uaed in a re-test of the studente. The covolueion might be reached, therefore, that 11tt2e we done bout misapelled worde. The noxt aren whe conoerned with whether or not senfor olasen had apelilng watehes. Table XIX showed the results. 


\section{ARTE $\times \mathrm{TX}$}

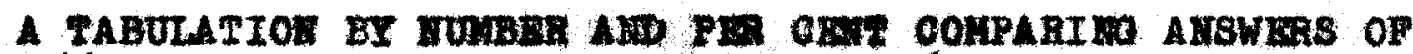

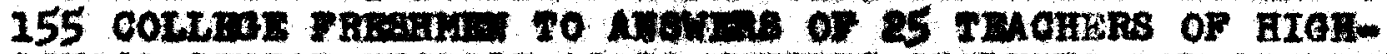

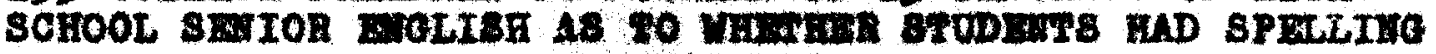
wrots

Spelilng Natohes

Tea

Io

Not answering
Englinh reachere

No. por eont

4

16

5
16

64

20
Colloge Proubmen

mo. per oont

$30 \quad 19.4$

$90 \quad 58.2$

$35 \quad 22.5$

Coneerning the question as to whether or not they had apelling tohos as anlor in high sohool, thirty, or 19.4 por oent, of the studenta answered that they d1d. MinetJ. or 58.1 per cent indioated that they did not have spelling matohes.

Four, of 16 par oont, of the teachers ahooked having had apolilng tohes. slxteon, or 64 po oont ohoeked no. From Information contelned in Table XIX, the conelunion on be resohed that mont of the studente did not have epeliling watoboa. sixty-four por oent of the teachere and 58,1 per oont of the studente ind loated this.

The noxt axea was oonocrned with whother or not endos olebsos studiod words that had been mienpoliod in thenes. Tab10 $\mathrm{xx}$ ahowed how many atuded those rorde from thomes. 
TABLE XX

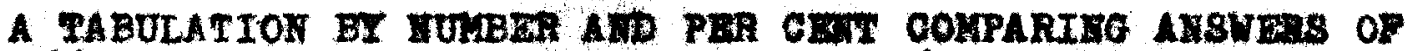
155 cotr.

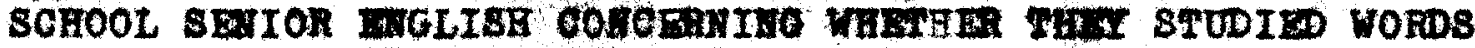
TEMT EAD BEA MISSPELID II REIMES

Studied words misoporied in thomes

Xos

No

not anawering
English Teacher:

Ho. per cent

20

2

3
80

8

12
College Proshmen

Do. per oont

When asked whethor they studied word that had boen miaspellod in themes, elxty-nine, or 44.5 por cont, of the college freshmen Indioated they did. Forty-seren, or 30.3 per oent indicated they did not.

Twenty, or 80 per cent of the teachere stated they taught words that had boen misopellod in thomes as part of the epelling, only two, or 9 per cent, wald they did not. Many more teachere Indlcated heving taught worda that hed been misepellod in thomes than did atudents Indio ate having atudiod. The poroentege was almoat twloe us groat. From data contained in Table $\mathrm{xx}$, the conclusion can be reaohed that studentu in sentor maglioh studiod words that had boon misepelled in thewes, as indiented by 25 texohom In Loulevills and Jafferson County and 155 oollege frosmen at the Onlversity of Loulavilio. 
The next aroh includod in the questionnalre in an attempt to dotermine what whe taught in high-sohool sentop Inglish is that of rooabuiary etudy. The scores for this area are shown in rable $\mathrm{xxI}$.

\section{TABLE XXI}

A TABULATION BY MULBER AID PRA CETT COMPARIMO ANSUERS OF 155 COLLDOE PRESKMER AMD 25 TEACHERS OP BIOH-3CHOOL SHIOR

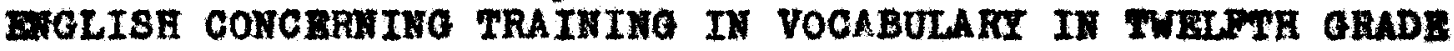

Vocabuiary Study

Lessone in voobbuiary
Baglith Teeoherw

No. per cent
Co1lege Presheen

Ho. por cont $\underset{\text { pronumotiction }}{\text { Protioe in }}\left\{\begin{array}{l}\text { Yos } \\ \text { no }\end{array}\right.$

Practice in oyllabloation

( No

Study Hoaninge
of words $\left\{\begin{array}{l}\text { Yos } \\ \text { yo }\end{array}\right.$
$21 \quad 84$

8

76

12

68

28

24

96
$87 \quad 56.1$

$52 \quad 33.5$

$51 \quad 32.9$

$86 \quad 55.5$

$56 \quad 37.4$

7347.1

$102 \quad 65.8$

$34 \quad 21.9$

In reepones to the queation portaining to the study of voenbulary, Table XXI showed thet elghty-ueven, ov 56.1 por oont, of the atudents sald ther had lessons in 
rocabulery; while fifty-two, of 33.5 per cont, sald they did not. Fifty-one, or 32.9 pos oont Indioated that thoy had pract100 in pronunolation, wh110 itghty-11x, or 55.5 por - ent anld they did not. Or the group flety-olght, or 37.4 per cont, Indieated that thoy had proetioe in erliableation; seventy-three, or 47.1 per oont indicated that they bad not. The largent number, 102 , or 65.8 per cont indieated that they atudied the moaninge of words; thipty-four, of 21.9 por oont indicated that they did not.

Twenty-one, or 84 per cont of the teaohers indloated they gave lessons in rocabulary; two, or 8 per cont sald they did not, Hinotoen, or 76 per eent, indioated they gave practioe in pronuneiation; threo, ox 12 per cont, sald they did not. Seronteen, of 68 por cont indicated having given preatice in eyllableation; seven, or 28 per oent sald they did not. Twonty-four, or 96 por oont, indicated that they taught moanings of words. Threo did not answor this question, but no teacher indioated that she did not wach the meaninge of words.

In oomparing respenses of the students to reaponses of the tenchers, "tudents anwered "no" more often than did tokohoras in fact the atudy of pronumelation and eyllabloation had more answers "no" then "yos". Among the tocohers 84 per cont roported haring required lessone in rocabulary, as oompared to 56.1 por cent of the student: 
who had studied roobulary. Seventy-alx per cont of the tencher roported having required preotioe in pronunolet1on, as compared to 32.9 per cent of the students who studied pronunolation. sixty-elght por eant of the toucher: roported heving required the atudy of monings of words, as compered to 65.8 per cent of the tudente whe atuded vord moaninga .

In the next arve on attempt was made to find out how often Ilterature was taught. Fable XXII showed the reablts.

\section{TABLS XXII}

A TABULATIOA BY MUMBER ATD PBR OBRT COMPARIMO AMBWBAS OF 155 COLLBOE FRESHMEA TO ANSWBRS OF 25 TEICHBRS OP MIOH-SCHOOL SEMIOR BMOLISH RERAFDINO AMOUNT OF TIME SPBNT II THE 8TUDY OP LITERATURE

Studied Literature

Inglish Toachers Mo. por oent
Co11 oge Proshmen Ho. per cont
One semester

nt1re yoar

two deye wook

Three days woek
9

6

2

6
36

24

4

24
61

41

18

29
39.4

26.5

21.6

12.3

sixty-one, or 39.4 por cent, or the pupile ahoeked one semoster as the amount of time spent in the tudy of 11terature. Porty-one, or 26.5 per oent indleated that thoy studied 11terature the entire jeer. Elghteen, or 11.6 per eent, 
Indicated that they atudied 11 terature two day each weok. Mineteen, or 12.3 per ent cald they studiod 11 terature throe days oach wook.

Mine, or 36 per ount of the teachers Indice ted that 11terature vai tanght one comesters $81 x$, or 24 por cont, uld an ontire yeary one, or 4 per cent, 110 ted two daye ouch wook; and asx, or 24 por oont Indianted they tanght 11terature three daye eooh week.

In regaxd to the study of 21 terature teachore and atudenta egreod that at moot sohoola the indioatione vere thet I1terature was taught dally for one semester or throe perlody each weok for the entize year.

Host sohools inoluded something during the year with the study of 11terature. Table xXIII showed what atudents and teashore Indicated was atudiod in ocennootion with I1terature during the sentor year of high-sohool Figlish.

\section{TABLE XXIII}

A TABULATIOM COMPARIMA ANSWEBS OF 155 COLLEO FRESTMEN TO

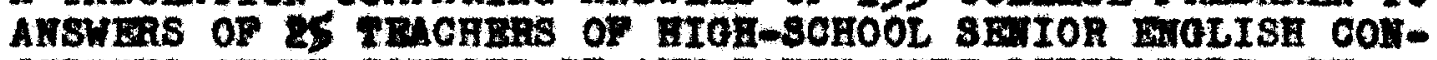
CERIIINO OTHER COURSES IF AII TAKEA WITH LITERATURE; BY MURIBER AID PER CEATP

Studied with 11toraturo

Grasmar

Othere
Inglish Teabherw

Ho. per eent

20

80
College Frenhen Io, per cent $89 \quad 57.4$

$7 \quad 4.5$


Tablo XXIII showe what the tudente atudiod along with 11terature during the senlor jear of high sohool. A wajority. - Ighty-nine, or 57.4 per cent, studiod grammar. One, or .6 por cont, Indicated thet he or the studied usage; four, or 2.6 por cont Indlated that they otudied speoch and two, or 1.3 por cont indleated that thoy etudicd eroutive miting during the enior joar along with the otudy of Ilterature. Twenty of the teachers, or 80 per cent 11 ated gramar as the sub joot studied with literature during the enlor year In high-wohool knglish, only a few otudents lioted usage, epeooh, and orentive writing.

In comparing the responses of the students to the reaponses of the teachere, the data in rable zXIII indleated that gramer bas" the highest percentage in both instanoes, 80 per eent for the teachers as oompared to 57.4 por cent for the students.

After determining that grasmar was taught with I1terature, the noxt step wa ineluded in the questionnalre to see what 1toms were taught in the course of gramar. Tablo XxIV showed the reaults of this inquiry. 
raBLe xxIv

A TABULATION COMPARIMO EY IUUBER AID PER CETT THE AMSUERS

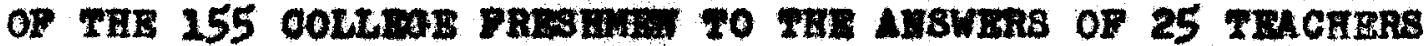
OP HIOH-SCHOOL SEIIOR EOLISF RXOARDING WHAT THRIR STODY OF SEIOR HTOM-SCHOOL GRAMAR HOLOPED

What ineluded in grammar

Parts of epesch

Phraseg

Ola uees

Bentence structure

Pronetuation

None

on alde

Mistakes from writing
Inglish revoher

No. per oent

19

19

19

23

20

College Freahmon Ho. per oont

$72+3$

20461,2 $105 \quad 67.1$ 10567.1 11372.9 $4 \quad 2.6$ 1.6 $1 \quad 6$

Tab1 XXIV thowe what the studente otudied in gramer. A majority, 112, or 72.3 per oent, Indioated that they atudied the parts of speoh, as oompared to 19. of 76 per cent of the teachers whe required the otudy of the parte of epeoch. Noxt, 104, or 67.1 per cent Indloated that they atudied phrases, as compered to 19, or 76 per cent of the teachers who requined the otudy of phrasen, One more, 105, or 67.7 per ant, Indlosted that clausen vere a part of thelr gramar, de compared to 19 
or 76 per cent, of the teechere who indseated the seme. An oqual number and per cent of the atudents studied sentonec atructure, as compared to 23 , ox 92 per cont, or tho teacherw who required the atudy of sentenes etmesture.

The largent nuber 113 , or 72.9 per cont of the teachors taught punctuation as compared to 20 , or 80 por cont, of the etudents who studied punctuation. Four, or 2.6 per oent unld they atudied no gremuar; whlle, one, or 6 por oent, sald he or the studied grammar oceasionalig. One stredent. or 6 per cont, Indioated the study of correctlons made in his writinge. These same india tions soem to be prevalunt amont the teachore also. reaoherw and tudents agree on what was taught, but teaohers' percentages were higher then pereontages of the atudente.

This setion attempted to determine how often gramans was taught. Table XXV oontalns number and poroontages Indloating each 1tow. 
TABLE XXV

A TABULATION, BY MUnBsR ABD PBA CERT, BROHIMO hOW OFTE

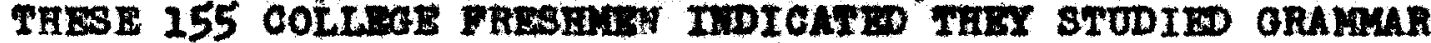

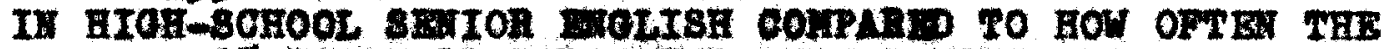
25 THCBBRS INDTCATWD THEY TAEOHE ORAMMAR

How orten

One semester

Intire year

Three days each week

two days each week

As orror showed noed

One-fourth joav

P1ve weeke
Dallah Teaghor:

Ho por oont
36

2

5

4

2

1 0o11ege Freahnen

Io. por cont

omooking the time spent in the otudy of gramen in the enlor year of high-ebhool. fifty-five, of 35.5 per oont of the atudenta Indiouted that they apent one ceneuters eloren, of 7.1 per oent, Indioated that thoy opent the atiro

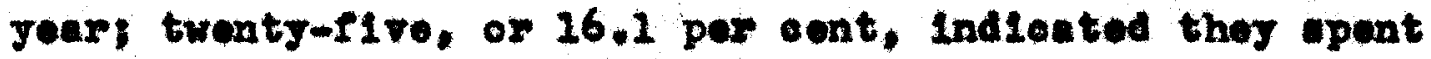
two daye oech veok; and seronteon, or 11.0 por cont indieated they spent three daje each weok.

Iine, or 36 per cent, of the teachors indicated that grammar was atudied one someater; five, or 20 per oont 
11ated two deye each weok; and two, or 8 per cont, atated that grawnar was teught three deys each week.

The percentages are lallar when comparing reaponses of the teachore to the reaponses of the atudents. Mo teasher stated that grawer was taught the ontire yoar; however, eleven, or 7.1 per cent of the students gave that answer. They were probably among those that otudled I1terature and grammar all jear.

The next area dealt with is what was dono in romedial reading. Table XXVI showed what was done in the claeses of these students and teachora aurveyed.

\section{TABLE XXVI}

A TABULARIOU BY TULBER AMD PER CBRT SBOWIHO WRAT WAS DONR

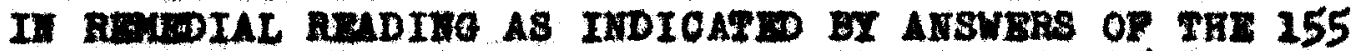
COLLEOE PRESEIT COMPARD TO AMSWERS OF THE 25 TECHERS OF HIGH-SCHOOL 8MIOR BULISH II LOUISVILL AD JUPFRRSON OOUTYY

What done in

Romedial Reading

Aud10-vianal devioes

Eye examinations

Roading toats

Mone
Bugliab Toabora

Jo. per oont

12

12

16
College Freabuon

Bo. por oont 
Table XXVI howed twelve, or 7.7 por aent, of the atudents indicated the ues of audlo-viauel devloes an ald in remodicl rodingl twontr-five, ox 16.1 per oont, had oye examinaticass rifty-two, or 33.5 por cont, Indieated that they had reading toate; and forty-1x, or 29.7 per oent indloated thet nothing was done for them in the way of romedial reading.

Throe, or 12 per cont of the teachers indionted the use of aud10-visuel deviees; three, or-12 per ant eald the student. had oye examination in connootion with romodial reading; four, or 16 per oont, lndloated studente had reading tosts. One teaoher named roading and the interpretation of passages.

In comparing the roaponses of the teachere to the respontes of the students in rogard to things done in the arce of romodial reading. 12 per cent of the teachere Indioeted oye examinations as compared to 16.1 per cent for the atudents; latteen per ont of the teachere indieated roading tosts as oompared to 33.5 por cont for the otudents. Wo teacher indicated that nothing was donet whereas, 29.7 por oent of the atudeats gave that anawer.

Whother examinations should or hould not be administered be been dobated wany timses. Table XXVII showed indioetion: of the 255 students and 25 teachore conoorning whether they had examination in the sonior year of high achool. 
XABLE XXVII

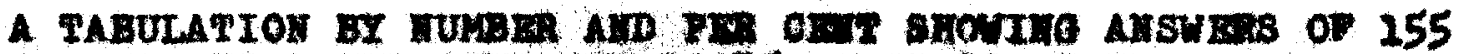

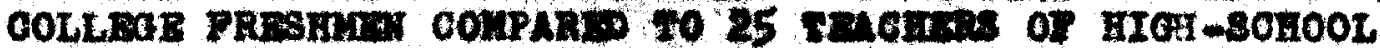

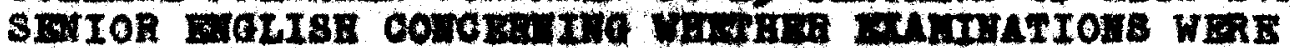

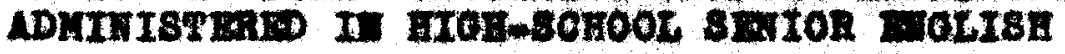

wraminetionst

Diglith reahor

Ho. por owt

Tos

Io

Hot answering
23

0

2
92

8
Coltege Freamen

7o. por oont

$136 \cdot 87.7$

$7 \quad 4.6$

12. 7.7

Table XXVII ahowed the anewers of the student: and the tenohor ooncoxning whother or not the students had exam1-

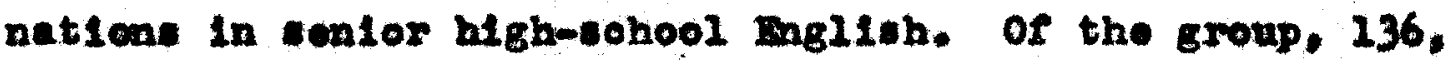
or 87.7 por cent, atated that thoy bad examinationes wh1le eeven, or 4.5 per cent cald they did not. Twelve, or 7.7 per oent, of the atudeats did not answer this queation.

Irenty-three, or 92 per oont of the teachers Indie ted that examinatione vor adninistered; howerer, two, or 8 por ocnt, Ald not andwer this question. The conolusion oan bo renohed that wout teachers of high-wehool wonlor Bnglish gave examinetion or towt at some time during the jear.

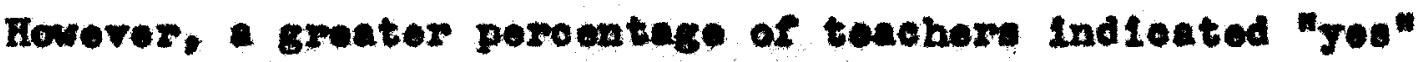
than did atudents.

the noxt area showed what type of examinatiens wore

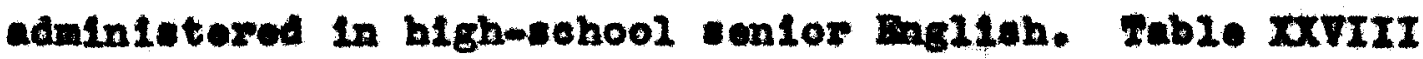
chowed the revalts. 


\section{WaLs XXvIII}

A TABULATIOZ EI MUABR AMD PBR CBMT SHOWING VEAT TXPE OF

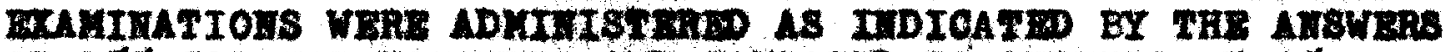
OF 155 COLLEOE FRESHA ADD GOMPARE TO ABSWRRS OF 25 TRACHERS OF HIOH-BCHOOL SEITOR EuOLISH

Type Examination

$$
\text { mgliah Teachera }
$$

No. por cont

saag

True-raias

Haltiplo-oholes

Completion

25. 100

11

23

17
44

52

68
Colloge Freshmen

Ho. per cont

112

$72 \cdot 3$

69

44.5

78

50.3

$90 \quad 58.1$

rable XIVII showed that 112 etudents, of 72.3 per

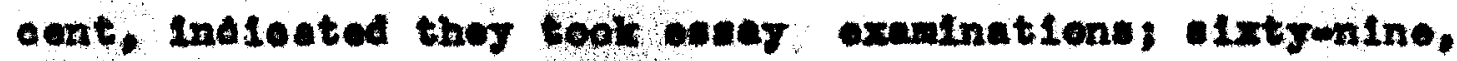
or 44.5 per cont, true-ralses seventy-aight, or 50.3 por ent, maltiplemoholeer and ninets, or 58.1 por aent complotion.

Iwenty-rive, of 100 por cent of the teachers ould they gave easay-type erratinations; elevon, or 44 per eont, stated trueralse; thirteen, or 52 per oont, etated multiplooboleo; and soventeon, or 68 per eent, indice tod oompletion. Fra Information eot forth in rable XXVIII the oonelusion can be ronchod that eraminetions of all four types were adminlstered; however, the one named moat of ten by the teachors and students was the saeg oxamination. 
Perhaps the escay-type exemination 1s more adeptable to gramer and 11 terature. The poreenteges of varlous types of examinations are Mighor wowg the teachers exoept in true-ralne where 44.5 por oent of the otudents Indieated taking true-false oxaminations as compared to 44 per oont of the teachere who Indie ated giving the truc-faleo examinatione.

The next attempt was to find out how often those examination. were adminiatored. Table XXIX showed the rosulte of this inquiry.

\section{eABLE XXI}

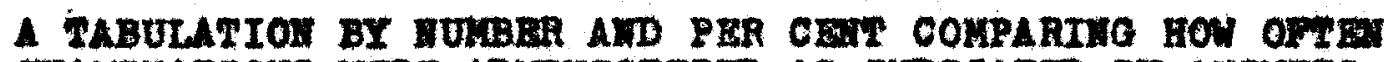

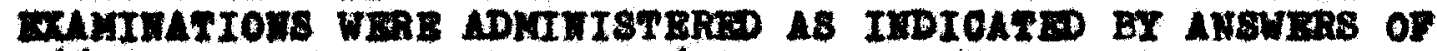
155 COLLEAE FRESHME AND 25 TEACHERS OF HIOL-8OROOL SEAIOR EOLISH

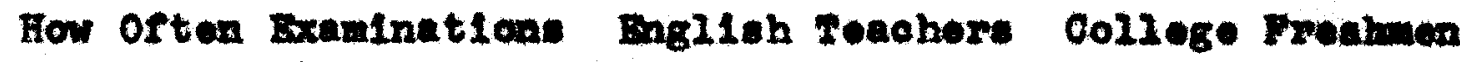
Adminiatered No. per oent Ho. por oont

\begin{tabular}{|c|c|c|c|c|}
\hline Wookiy & 3 & 12 & 32 & 20.6 \\
\hline Sont-weokly & 3 & 12 & 27 & 17.4 \\
\hline Nonthly & 6 & 24 & 62 & 40.0 \\
\hline Ind of unit & 4 & 16 & & \\
\hline Oneo each term & 2 & 8 & 15 & 9.7 \\
\hline Others: & 7 & 28 & 6 & 3.9 \\
\hline
\end{tabular}


When asked how often those examination wore edvinisterod, thintj-two, or 20.6 per cent of the studente roplied weokly; twonty-ueven, or 17.4 per oont, ropl10d eoni-weokdyt ixty-tro, or 40,0 per cont ropliod monthly; fifteon, or 9.7 poz cent roplied once onoh torm. s1x, or 3.9 per oont gave other answors as timos whon examinatieno were administored.

Three, or 12 per cent, of the teachers Indloated that examination, wore administered woekly; three, or 12 per cont. sald somi-wookly; alx, or th por oont indioatod monthis: two, or 8 per cont, 11 sted once each term; and ooven, or 28 por cont named others. Four, or 16 per cont, of the teachers answered the end of the unit of work. Monthly examinatione rocelved the highest pereontage of votos from toachere and otudents.

The next area was ooneerned with the time the examination papars wore returned. Table XXX showed results a Indieated by 155 o0120ge fromen at the Univereity of Louleville and 25 toachers of high-achool sonfor foling In Loulevilie and Jorferson County. 
TABLE $\mathbf{2 0 X}$

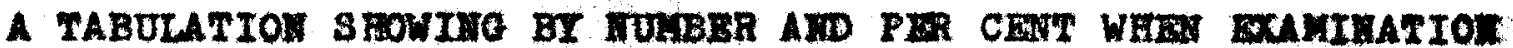

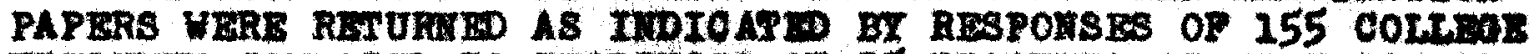
FRISHMEM COMPARED TO RESPOWBES OF 25 TEACHERS OF KIOH-SCHOOL 8wTOR EROLISH

Examination

Papere Retumed

Day following

Wook sollowing

Not at al1

\section{Inglish Teachere}

Ho. per cent

13

8

1
52

32

4
Co21ege Proshmon

To. por cent

3120.0

$96 \quad 61.9$

$21 \quad 23.5$

opon being asked then examinetion papere wero returned, thirty-one, or 20.0 per cent of the students answered the day following, as shown in rable $x x x$. Mnoty-alx, or 61.9 per cent, stated the woek following. Iwonty-one, or 13.5 por eont, wald not at all.

Thirteen, or 52 pont of the teachers indice ted that examination pore were returned the day following! 1ght, or 32 por oent otated the wook rollowings one, of 4 per oent stated not at all. reachore etated thes roturned papera cooner than studente a indlonted by the above table. Only one teacher Indloated "not at all" as compared to 20 , or 13.5 per cent, of the tudents.

The next area is conoerned with what booene of the examination papore. Table XXXI howed the noores Indlostias what beeame of examination papers an indieated by 255 
college frosbmen and as teachors of sontor Baglish in Loulavi11. and Jefferson County.

\section{WABLE $\mathbf{x x T}$}

A COMPARISO OF THE RESPOUSES OF THE 155 COLLEAE PRESHMET

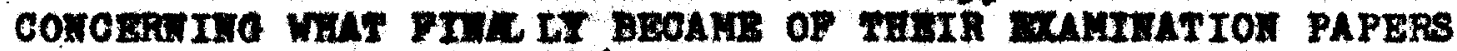

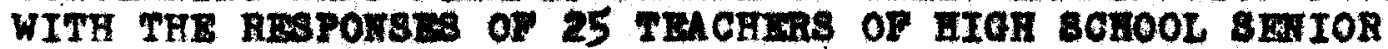
EOLIBA, TLEOLATS BY MUNBER AND PE OER

How Papere Were

Dieposed of

Part of porranont record

On r110 in the clasereon

Deatroyed by the student

Destroyed by the tenoher

Don't know
Englioh Teeohers

No. per oent

36

38

24.5

7

28

16

10.3

5

20

55

35.5

6

24.

$25 \quad 16.2$

8

5.2

Coneerning the diaposition of examination papers, rable XxxI indieated that thinty-01ght, or 24.5 por oent of the students ateted that examination papers beoame a part of the permanent rooor of the student. 81xteen, or 10.3 per cont, Indleated that the papere wero plaoed on filo in the olaseroom. Pifty-five, or 35.5 per cont oteted that the exarination papers were destroyed by the student. Pwenty-rive, or 16.2 por oent atated thet 
examination papers wexe destrojed by the techer. Bight. or 5.2 per cent, wrote in the exprosilion, "don't know." IIno, or 36 per eont, of the teachors stated that examination papore beane a pormanent part of the studonta" reoords; soven, or 26 por ent, stated thos wore put on f1le in the olaservom, five, or 20 por oent steted they were destroyed by the teachir and no teabrer gave another answer. A larger pereentage of studente indloated papers were destroyed; whereas, larger peroentage of seachera Indicated the papera beoume art of the sohool reoorde. The next seotion was ocneerned with the mothod of seleoting home roading. Table xxII showed masults al teachore and studente shooked andwers to the inquimiea.

\section{TABLE XXXII}

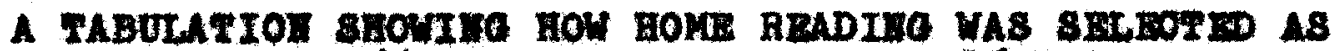

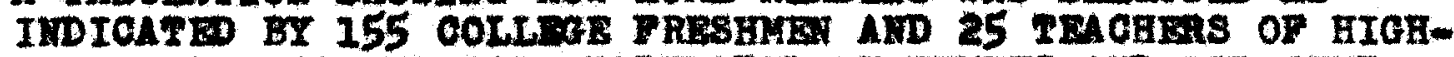

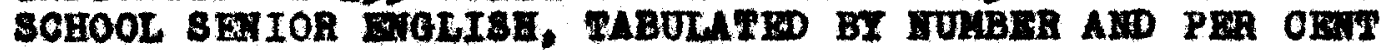

Books Selected From

Engliah Teachers

Ho. per cont

Published roading lints

Listo assigned by the teacher

List: assigned by the sohool syetom

Othere
$13 \quad 52$

12

8

32
College Freahmen No. per cent 
Aa shown in rable txaII. fifts, or 32.3 per cent, of the studente oulooted rouding from publishod reading 11 st.

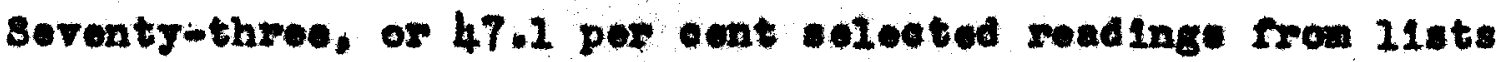
eosigned by the towoher. Inirty-ent, or 20.0 per cont, seloctod roading from list aceigned by the nohool ejatem. One student, or .6 per oent, Indieated that the oeleetion of reading was left to the judgement of the atudent. Thirteen, or 52 per cont, or the teaoher etated tholr reading was taken from publiwhod reading lists oleven, or 44 por cont of the etudents stated the 11 ats were anelgoed bj the teacher; elght, or 32 per oent, of the atudents atated that 11sts wore asalgned by the achool ogatem. Publiched reading 11sts, and lists aselgned by the teacher wore ohockod most often, but more students than teachers oheoked 11 sts aselgned by the wehool syatem.

The next ares was conderned with how students were required to report on roadings. Table xxxII glves the results as indioated by the 155 students and 25 teachers. 
A TABULATIOI SHOWTMO HOW STUDEATS WERE MBQUIRED TO REPOR ON FEADING DONE OUTSIDE OF CLASS II HIAH-SGHOOL SEIIOR

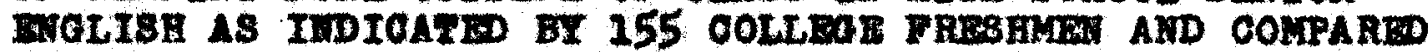
TO METHODS TEACHERS OF NIOH-SCEOOL SEIOR ENOLISH IMDICATE THST MENUI ThD

Book Roporte

Englioh Toaohor

Ho. per cent

Oral roporte

Writton roports

Cumulat1ro roading 11: ts:

Hone $u_{4}$

15

3

12
College Drowhnon

I0. pos cent

With referonce to reporting on outside reading. Tablo XXXIII howed that berenty-F1re, or 48.4 por cent mado oxul roporte; 103 , or 66.5 por oent, mede written roporte; s1x, or 3.9 per cont, mado oumulative reading 21ets; and four, or 2.6 per cent, made no responee. Fourteon, or 56 per cent, of the teachers atated that thoy required oral reports on readings done by otudenta; Iifteon, or 60 per cent, steted thoy required writton roports, throe, of 12 por sent, atated oumulative roading 118te wore kept. Sows ohecked both or perhaps 211 three. Four students, or 26 per cont, Indloated no roport, no teacher Indicated "none" as the anmer.

An attenpt was made to determine what motirated thoee students to read. Table XXXIY gives the responses of the 
155 colloge freshmon at the Unfrerafty of Louisville ind the 25 teachere of high-achool sentor nglish in Loulevilie and Jefferson County.

\section{TABLE DXIV}

A TABULATIOF COMPARTUG ITEMS CHEOKED BY 155 COLLDOE FRESHMEAT

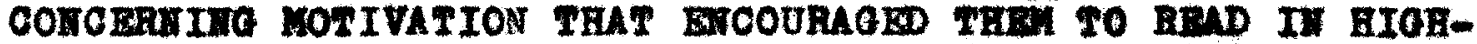

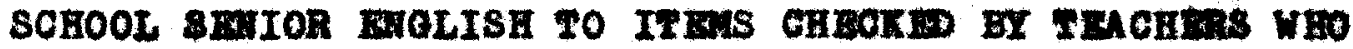

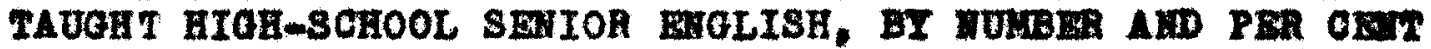

Motivations

Maglish Toachors

Yo. per cont
College Prebhan

Ho. por cont
Recordinge

ReVL Owe

Posters

Book Jaekote

Hovie:

Parta related by teaoher

Television

Rad 10

Home Library

Parte rolated by atudent 12

Asalgned, requlred, sorus, coupelied, ote.

Ione

$\begin{array}{rrrr}3 & 12 & 15 & 9.7 \\ 10 & 40 & 37 & 23.9 \\ 5 & 20 & 11 & 7.1 \\ 6 & 24 & 21 & 13.5 \\ 7 & 28 & 31 & 20.0 \\ 12 & 44 & 64 & 41.3 \\ 1 & 4 & 10 & 6.5 \\ 3 & 12 & 8 & 5.2 \\ 1 & 4 & 9 & 5.8 \\ 11 & 44 & 47 & 30.3 \\ 1 & 4 & 9 & 5.8\end{array}$


Tonohere and atudent allke oheoked many of the Items 21ated as motiration for reading. Parte rolated by the toaoher and parte rolated by the student were ohooked most often by the atudente and the tanehers, Ten, or 6.5 por oont of the atudente stated thore wa no motivation. Iine, or 5.8 per cont, of the studente etated reading celeotlens wore only asigned, required, te, Cnly one teacher Indicated essignod aeleotione. Some otudenta rand only bookuse it is required. 
CHAPEER VII

Bumary and Conelusion: 
The purpone of the paper val to compere the atatenente of 155 oolloge Iromimen at the Dalveralty of Loulevil1. to the atutements of 25 touchere of high-wehool senior Ingliah In Loularille and Jeffereon County, Kentruly, ceneoralng what was taught in high-oohool sentor magliah.

Information was weoured from the reat Bureat at the Univeralty of Louistile concerning agea; wohoola from which the froahmen cames total soored on the Paychology, the mgl1sh, and the Gonorel oulture portlone of the Aohlorement test whloh was adninistered to them upon applioation for. ontrence at the Dnirorsity. This information was seoured for the ontre 359 students onrolled in the froshman olese for the fall and epring terwa of the $1952-53$ echool rear. The ages ranged trow 16 jeers and 10 monthe to 45 year.. with mean age of 19 years and 19.77 monthe The mean pereentile ceowe for the group of 359 oollego Ireshmon on the teat by the Ameriean Counell on

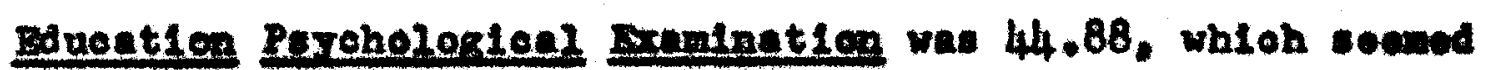
to Indieate that the group was of norral intelilgones and oppable of doligg everage work required of oollege freshen.

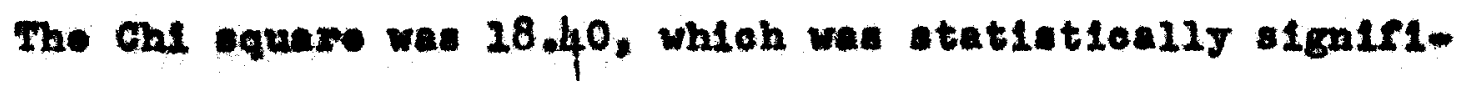
oant at the 5 por cont level. 
The mon pereent11, soore on the Cooperative Brellah Teat was 35.48 . Th1. Indloatod below avorage group in tho comprohonsion of ornl and writton ocmpostion. The Chl equare was 90.10 whteh was elgnifleant at the 1 pop cont lovel and Indieated that the group surveged differed algnifleantiy from the normal group.

The moan percentile soore on the ceoparative generel Culture geat was 33.78 . Thlo soore indisatod below noxmal group in achlevement in opite of the fact that the atudentes abilities to learn were normal. The chl square was 125.12 whioh was ignifloent at the 1 per cont level and Indieated that this group alffored algnifleantly from the normal group.

The questi onnalre, What Iou Studied in High-yohool Senlor Englich was edminletered to 155 oollege frowmen ohosen at random at the Univerefty of Loulevilie in vay. 1953. These queatlownal res were adminiatered in rogular Inglish oleseew. The student: were adked to anowor the questions truthriziy and as oompletely as pousble.

The seme quostlonnelre was edinlnieterso to those teachers who taught high wohool. encior rigileb at tho obool In which thoy tanght in May, 1953. Only one toachor railed to retura the questionnalre. Somo of them fllled in the quoetlomalre imediately, wh1le others asked to have tiv 
to oomplete them. These wore retumed by mall upon coupletion. Those toushore or high sohool wenlor English in Loulavill and Jeffereon County. Iontwoly, were acked to anewer the questlonnalre from the otendpolnt of what thoy taught in high sohool towtor Inglith.

The renpewee of the 155 oolloge fremben wore oomparad by number and per oent to the reapensed of the

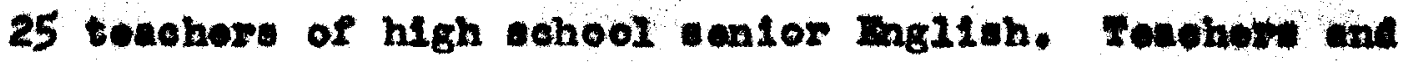
otudonts ild not agreo conoeraing what was taught in ilgh whool senfor Bnglieh, tencher giving the wore ravorable reopenses. However, Interpretation of terms used in the questionnalro wes problbiy affieult for tho studonts. Perhepe the etudente did not alware reoognise or remomber what he had been teught. Many of the students had been out of wobool for a Iow jwars and did not remober too 0learly what they had otudied to high sohool sonfor minglib.

Coneluelons. The following eonelustons were readhod: 1. The atudents' coneopt of toples oovered in high-

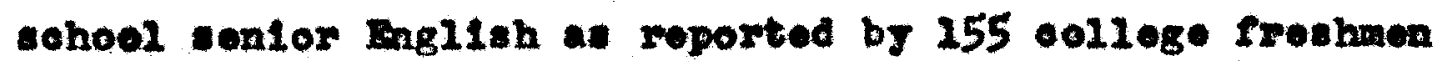
was not the same as the ooneppt the teachers of High-eohool

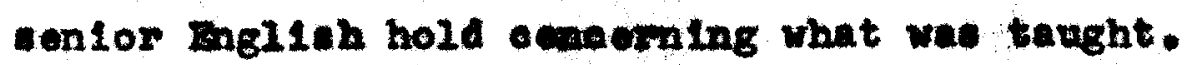

2. Teacher gave nore favorable replien to the questiomatre than did the students.

3. The jajority, 61.9 per oont of the tudents and 92 por cont of the teachere, Indleated written work of wane 
Kind was done ono each week or more often; more atudents than teachere indleated oceasionaliy. 29 por cent for the students and 6 per oont for, the toachers.

4. The mojority of teacherw, 72 por cent sald the students wrote themes onee ench weok ar more orten; whorese, the majority of studentw, 65.8 per ecent, cald only oocastonelly or Less.

5. Or the studente, 71.6 per ont seld tecehorougsestions furnished more toples for themest of the tesohors, 88 per oent sald porsonel exporienes rumiohod more topios for thomes.

6. Teachors oheoked arger vaxlety of types of writing then did atudenta.

7. Pexentages indioating proparation for writing was higher among the toachers than the studonts, 64 por cont of the teachers and 32.3 per cont of the students Indleating they wrote an outline, 40 per cent of the teachors and 14,8 per oont of the atudeate Indieating thoy propared 'model, 68 par oent of the teachor and 49.0 per ent of the atudente indlosting they ha a type of writing explained to them. Ho toacher indioated no preparation; whereas. 9.7 per cont of the students did. B. Vartou ways of obooking and reviaing thomes was wedt but judging from item oheoked by atudents, no cortale way of ohooking and roviding thomes was uoed in the teaphing of hlgh-wohool sentor Bnglish. Teachers indleated nore detalled grading of thomes than did the atudente. 
9. Letter graded were given in high-sehool eonior English as Indioated by 84 por cont of the teachere and 74.2 per cont of the etudente.

10. Toachors Indieated that papere were rotumed noro proxptls than $11 d$ the studeates 96 per eont of the teabhers cald withln one weok or wooner, and 85.2 por cont of the students ald within one weok or cooner.

11. Host of the otudenta, 93.5 per cent, Indiented that elase olsouselon followed the return of corrected papers or that the errore wore polnted out by the teachoras 72 per eent of the teachor Indleated audlo-visual ald. 12. Hore teachers then otudente, 64 per oont as compered to 23.9 per oont indicatiod that papere were rowritton: 24.5 par oont of the otudents indioated no revietion.

13. Hore students than teachore, 47.7 por cent as o ompared to 36 per oent, Ind loated that themes wore destroyed by the student, just we wany tonohers, 36 por cont, Indieated that they boceme a part of the otudent's sobool record.

14. Frem the group survered 76 per ecat of the toachers and 61.3 per cent of the studeats agreed that they hed formal lessons in epellingt however, moxe teachors then etudente. 72 por cont es compared to 63.2 por cont, Indieated that spaling was written. 
15. Or the atudents, 48.4 por cont indiented that apelling worte ane from 14ate in texta: whoreas. 52 pes cont of the teachore indeated 1iete in texts and the samo number ald from errore in vritton work.

16. Studente and teachore are not in agrecient as to what is done about apelling orrore. The largeat nuber of studente. $27 \mathrm{~d}$ por ont, sald dicerdod; the largest number of toechere, 20 per oent, wale warked.

17. Toabher and studente are in agroement that epolling atchos were not hold in high sobol oenlor Bngl1sh, 44 por cont of tocehore caying no, and 56.1 pos oent of the atudente ceying no.

18. Hnost bwlec an many teachers as ald students Indiested having otudied alispolled worde from thomea, 80 por cent as compared to 44.5 por oent.

29. The number of techore Indieating atudy of roeabulery. pronumelation, arilebleation, and noeninge of words was weh higher than thut of the atudonte, 64 per cent as ocmpared to 56.1 per ent, 76 a compared to 32.9 per cent. 68 per ant a compered to 37.4 por cont, and 96 per oont as ocupared to 65.8 por cent, In that ordar.

20. Teachore and atudents agreed that in most instanees 21terature was taught one semester, 36 per cont for the teachers all compared to 39.4 por oent for the otudentes in come invtance both gramar and 11 toreture wore wtudied 
the entire jear.

21. Studente and techeres agreed that gramar was studied as a companion oubject to 11 terature, 57.4 por oent of the atudents and 80 por eent of the teachor enying ros.

22. Of the group ourvegred 76 por oent of the toachers as ocopared to 72.3 por oent of the atudente Indeated that the parte of epooeh was indivded in the study of gramert 76 per cont of the teachiry as compared to 61.1 por cent of the students thut phreses was art of the atudy of gramars 92 per out of the teachers as compared to 67.7 per cont of the studente Indicated that sentence strueture was Inoluded In the atudy of gramant and 80 per oent of the tesohers ad compared to 72.9 por cont of the atudents indioated that pronctuation was included in the study of gramer.

23. resohore and studente wore alvided on tholr Indioutloas as to bow often high wohoel centors atudied grament howerer, the largeat number, 36 per oent of the teachore and 35.5 per oent of the students indieated one compates.

24. I numer of alde vas holprul in remotial roeding as Indleated by teachore and studente! howover, 29.7 per ornt of the etudents wald nothing was done. Ho teacher inclestiod nothing was done. 
25. Of the group surveyed, 87.7 por oent of the students and 92 per oent of the tenobers agreed that examinations were adminietered.

26. Teacheri and otudente indleated four types of examinations. 100 pos oovt of the teachors and 72.3 por oont of the atudente ohooked puers 44 per ecat of the tecohere and 44.5 per oent of the studente ohoered rmeraleel 52 per oent of the teachers and 50.3 por eent of the tudents checked paltiple-Cholees and 68 par ornt of the teachere and 58.1 per cont of the atudente ohooked Complotien.

27. A laxge number, 48 per cont of the tenohers and 78 per cont of the students indicated that examination were edulinistered monthly to wookly.

28. A jortty, 61.9 per oent of the atudents Ind loated papere were rotumed the rollowing wooks whoreas, a mojorty, 52 por oont of the temoheri indleated papere wore returnod the deg following.

29. Students and toechare were not in agreement at to the rinal dieposition of papera. 35.5 par oent of the atudents ayling they were dentroyed by the atudente and 36 per oent of the teachors waying thos bowame a part of the studentel rooorde.

30. Nont of the teachers, 52 per cent, Indloated that the wartty of the reading was selected from a publithod 
reading 11at; whereas, the la ront number of the studente, 47,1 per cent, Indiested that rouding was selected from 210te ussigned by the teacher.

31. Tenchere, 60 per cent of the totil aurveyed, agroed with the studate, 66.5 por cent of the total survejod, that written roports on roading were used most often with oral reports noxt in $11 \mathrm{ne}, 56 \mathrm{per}$ cent of the teachors and 48.4 per oent of the students indeating thie.

32. Teachors and atudents Indieated a zerge variety In the motiration of readig; however. teneher chooked the highew por oent in orery type of motiration.

33. No teacher indicated 1nok of motivation.

This atudy was probably colored due to the ract that the teachere eurveyed oame from Louleville and Jerfersen County: wheread, the tudents surveyed oame from sohools within the elty of Loulerille, from county high whools and from sohools outalde the state. Two hundred three of the 359 atudents same from sohools within the elty of Loulevilie. IIghty-f1ve of the atudonts came from county high sohools or achoole out in the state. sixty-nine of the atudents came from sohoole outalde the state. Two etudents oawe from Kentude Military Institute. 
B1bllography 


\section{BrstroonupE}

Bird, Donald $\mathrm{z}$. "Indivituel1sed Pleocment in Commenteatlea

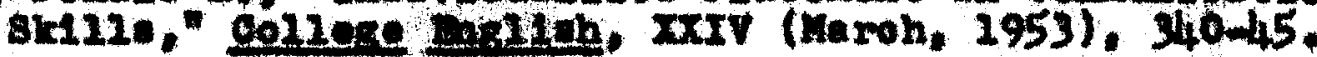

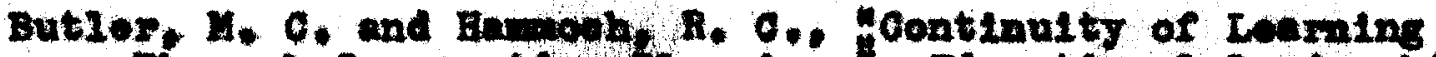

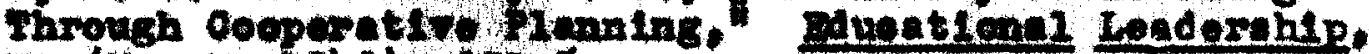
VI (Haroh, 1949), 391-5.

Consteln, 0. Fe, "Gramary How thuph for Collegen glearing Houne, $\operatorname{xat}($ Apri1, 2952), 486-7.

Davieg, A., "Dofenae of Freakmon," College Rngliton, III (riay, 1951), 440-8.

Duriceo, Frod, "Competenos in Ingliaht in Artiewletton Pine," Glearing House, IXV (Motomber, 1950), 149-52.

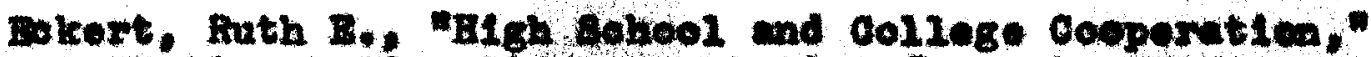

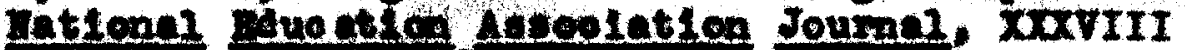
(Nobruxr, 1949), $90 \mathrm{~d} \%$

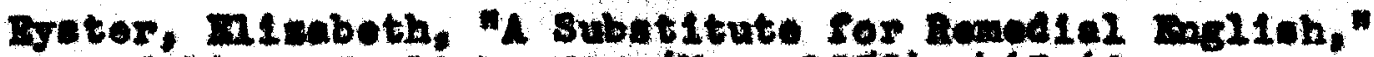
Collece Bnglish, xIV (May, 1953), 467-69.

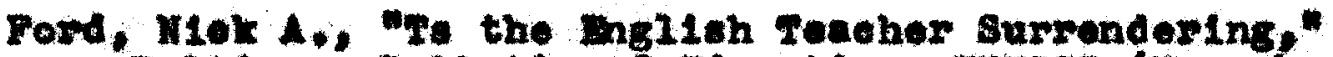

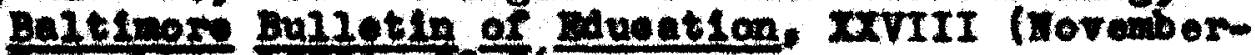
boetsor. 1950$) \cdot 23-26$.

Coxber, Weating and Bvaluation in the skills of Commication," Collese Bagliuh, IX (Apri1, 1948).

Grommon, Llfred H.. "Proparins High-sehool studeate for

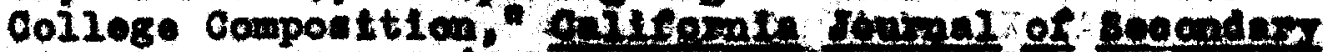

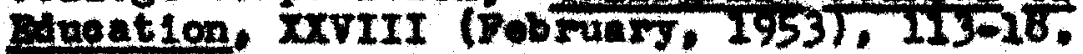

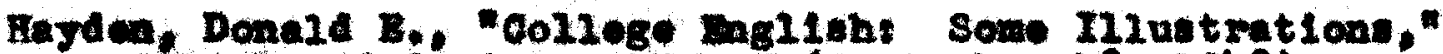
Qheol and sooletr. Irviri (september 16, 1948). Iutsen

Heraborg, Nax J., "The Toebher of Mnglish in the Noderm voria," Paglish Jownal, XL (February, 1951), 86-90.

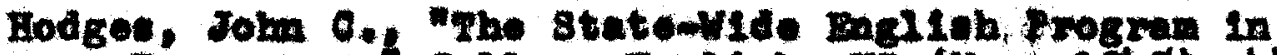

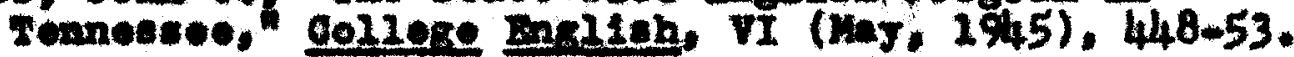

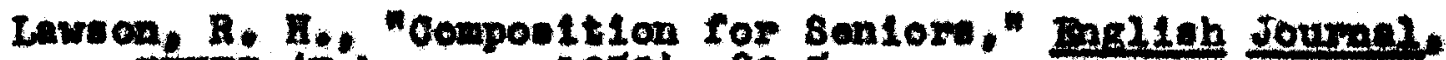
xomI (Tobruary, 1952), 82-5. 


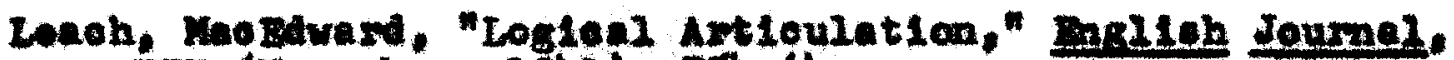
xxx (Torember, 1941), 754-64.

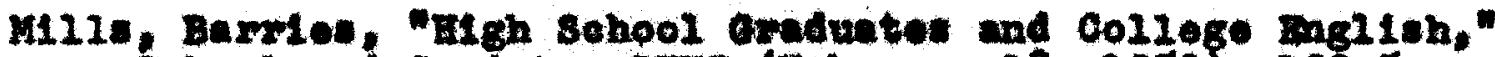
Sohool and soelety. texx (Fobruary 16, 1950), 102-5.

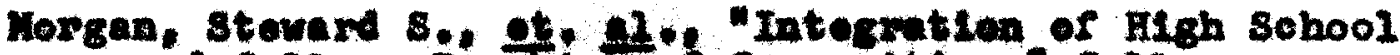
and Colloge reachin of couposition" collere

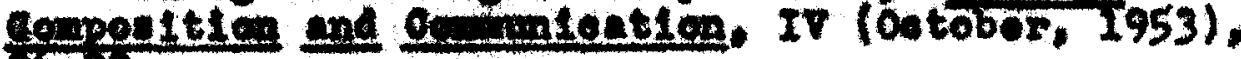
$96-99$.

Patt1110, X. H. and stout, Lompense, "Gooporation botween Secondary Sobools and Colloges, "Dorth Geatiol Leecele-

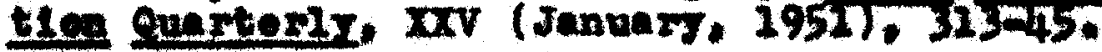

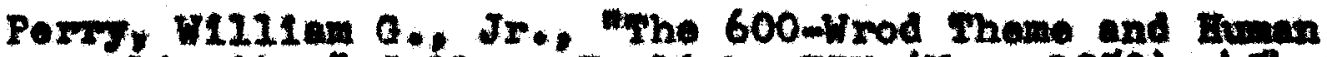
Dignity," coilege Bagliah. XIV (Hay, 1953), 454-60.

Peterson, Basll H." "High School and Junlor Colloge

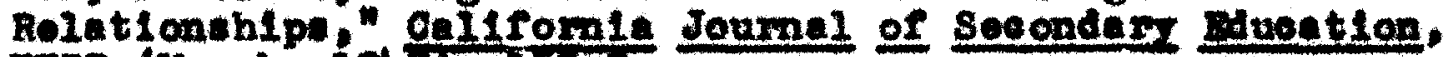
xxII (Haroh, iq47), 150me.

Pooloy, Robert O., Mohloring Continulty in High School and College English," College English, v1 (Deoember, 1944). $249-56$.

Pool oy, Robert C., "Forever Grammar," pulletin of Secondary Sohoel Prinoipals, (Fobruary, 1946), P. 45-49.

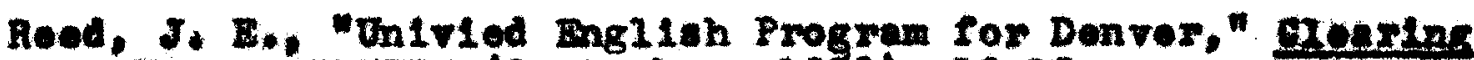
Eonse, xxvIII (Soptember, 1953), 10-12.

Rlee, Warner Q,. "Artioulation of Socondary School and

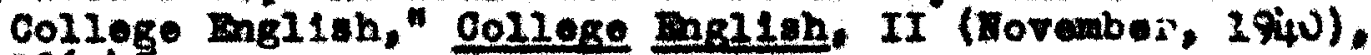
$136-45$.

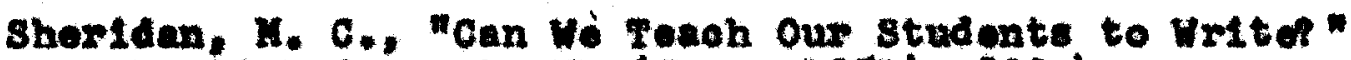
Pasilab Journal, XI (June, 1951), 320 4 .

Smith, Dora V.. "Problews of Artioulation in the Teaohing

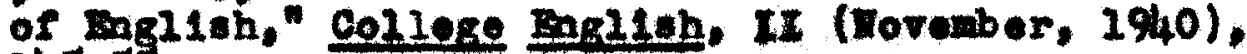
$145-55$.

Thorpe, Clarenoe D., Faotore of Orouth in the Languege Arts in College with Speciel Roferenes to Artloulation," College English, VI (March, 1945), 331-7. 
Thorpe, Clarenee D., "Knowl edge and sk1118 In Figlikh That

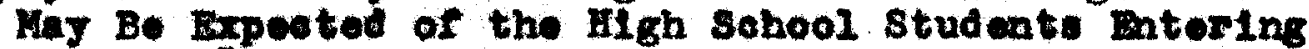

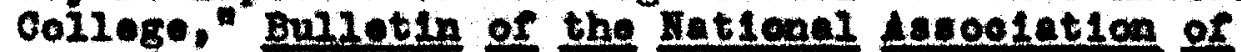

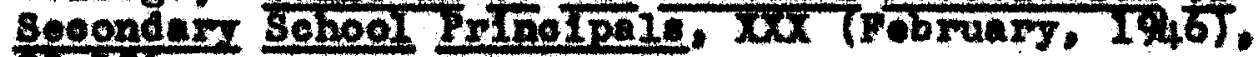
$93-106$.

Trecerant, Blanohe. "Problowe In Artleulating Bngliah Courses of Study," Bugliah Joumel. XXVII

(Apr11, 1948), 162-6.

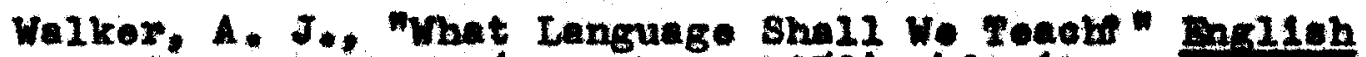
Joumal, XIII (November, 1953), 431-61.

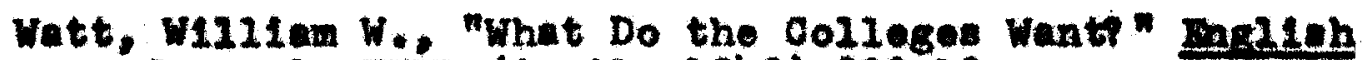
Journal, XXXI (Apri1, 2942) 302-13. 
APPEDIX A 
(1) About how orten was 'written work" (of ome sort) required of jou, in jour high sobool (sonior)

inglish ocurs of

Almodt dally.

2-3 times ench Week

Only 0oosestonelly.

Almout nover

Hone at all required

(1b) About how many (approximate number) plooes of Written York (of some somt) were required of you during the full sohool jear (tenlor)?

(2) About how often were you required to write 'themes" during your ontor Bnglish oourso in hlgh sohoolt

Almost and

$2-3$ tiwa estat

Lbout oine each wedk
On2y oecasionally.

Alwost never

Ione at all required

(3) About how many (approximate number) 'Thowes' wero required during the full ochool year (achlor)t

(3b) Wow the subjeots of these required 'thowes' taken from-

Liste round in the toxtbooks

Pereanul experlonees of the Etudent

suggest10an made by the teacher.

(4) What tjpee of 'writton work' wore required in jour cenlor Englieh courte In high whoolf (Chook as many of the tjper as epply.)

Blography.

attoblograpry.

derinition

comparison

book revion

analyele

sumery or provis

dosemptive
- herrater analjsio porvavelion oritioal añalys. torm papore pht losephlon atrounetong persenel expertendes outilnot aplanatro of
- probas.

(5) What comt of proparation preceded the writing of i $=9$,

writing of an outilne a 'mode1' prosented HFE explanution of the trpe of writing to be done 
(6) About how many of thene 'thomes' wore written-

- in claver -outa1de of olase?

(7) What wes tho average length of thomed vrittion in elaed -abert words $-\ln$ page (a)

(8) What was the average length of themes written outside of oleset

-about yords

- In page(s)

\section{QRADIHO AHD REVISIHE OF Thmas}

(1) How did the 'grede' your 'theme' papert

cooording to ow sort of reting, or mumieal oreter by writing in compotione?

by supplying proper punatuater

by Indleating places whore paragraph ahould begin

by indienting proper centenes etrueturer

by Indieating proper diotion

(1b)Did jen reoelve lletter' grades--A, B, C, D, P, eto. Yea no

(2) Hore rour 'thowes" usualig returned?

the dey after they wore written

the wook aftor they wero writton

Iot rotumed at ali

(3) Dow wero 'returned thames' ueualis bandica?

CIase disouscion?

Qenerel erroxs polnted out by tho teachere Audiowrieuni alde uegat

(4) How were these returned thenes rovies by the student - Ald the student writo in 211 of the cerrotioner wes the theme papor reminitien by the otudent? - did the student make marginal porwestlonst - other comments. 
(5) What uevalig beover of the thomes, fineliyt

-d1d they becoms a port of the student's eoh. rovord -were they put on $2 x$ in the laserocus -wer they destroyed by the tudionte -were they deatrofed by the teachorf -other ecromti.

\section{SPELLIMG}

(1) Did you have formal I weone in epolilinge

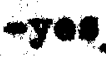

-no

(2) If jou did, what type Mritten___ - - ral

(3) Spoliling Lieta woro raken from what seurea

-liste from text

-I pot putalde text

-ilete teken from orrors in written rork -IInte made by student

\section{VOABBUA HX}

(1) Did you have lessone in voedbulary developmonth

-Jos

$$
\text { -no }
$$

(2) Did jou bave ari12. in pronunotation of worts

-yos $-n o$

(3) Did you hare practioe

\section{LTTERATURE}

(1) How muoh time was givon to the atudy of Ilterature?

-one cemerter

-ontive jour

-two dey pos weot ant

-thro deje por wi. in vrilablostion of wordin

$-\mathbf{J e s}$ no

(4) D1d you atudy the moaninge of wordin

- red -no

(4) Ereperled words wero basd a by - Alesertinds - Ignoritag

(5) Dic ron stwey aseopeliled woral in thoment

$-T^{\circ}$

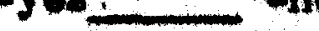

(2) If your ontire tim was not devoted to 1iterature, with what ooures wes it combinear 
omiman

(1) What was ineluded in pous atudy of gromente

-parte of epeson

-phrases

-olawe on

- entener atruotars

-punotuatien
(2) How orton ald you atudy gramsare

-one cemester

-ont1re year.

-two days wi.

-three daye por week

\section{RETEIAC REDTY}

(2) inat attempte were mods to laprore jour notbods of roading

-were audio-risual devises uned

- dia jou rooelve an oye examinatien

-did you have reading toste?

\section{ExAmarioms}

(1) Were examinations administered during your high abool (sonior) Bnglion ooure of

$-7 \times$ -no

(2) What type examinations vere you required to take - Easeay-type - MritiplowCholoo

-roue-ralxo - Completien

(3) How often wore oxaminetions edministeron

-wooks

$-\cos 1-\operatorname{con} 5$

monthly.

-once por term

(4) Were the extuminaston papore rotumed

the day following

the wook following

-not at 11

(5) Wero the oxamination papers ditbewased in elaset

$-\mathrm{Jen}$ -no 
(6) What finuliz bease of the exanination paperte -did they becowe a permenent pert of the atudent's cohool reooxar

$-700$

-were they pat on f110 in the claseroous

- Tee _

-were they destroyed by the student?

$-708$

wore they destroyed by the teachers

$-708$

HONE READTM

(1) Wow you requised to do oublide reading?

$$
-\mathrm{J} \bullet \mathrm{B}
$$

(2) Acquired home reading wes selooted from-

- prokitubed reading liata

-ilete and $1 \mathrm{gned}$ by the toneher

-ilst asalgned by the soh. ajotion

(3) Vore ptudente required to gire reports on resdinger -omal reporte

-avinative roadns list.

-aritten reports

(4) Wnat motichation oneouraged student: to rond

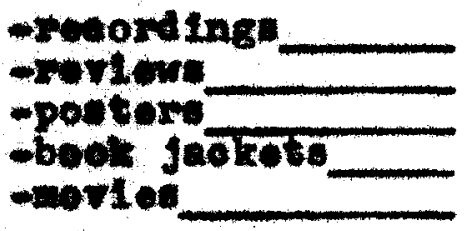

-perta reluted by the toacher

-televialón

-rad10

-homo IIb Thy

- parta releted by

another stud ont.

Dimfroutrres

sweangrious 